Article

\title{
From Decompression Melting to Mantle-Wedge Refertilization and Metamorphism: Insights from Peridotites of the Alag Khadny Accretionary Complex (SW Mongolia)
}

\author{
Marina Gornova, Anas Karimov ${ }^{D}$, Sergei Skuzovatov * ${ }^{\mathbb{D}}$ and Vasiliy Belyaev (D) \\ Vinogradov Institute of Geochemistry, Russian Academy of Sciences, Siberian Branch, 1A Favorskogo str., \\ 664033 Irkutsk, Russia; mgorn@igc.irk.ru (M.G.); anas@igc.irk.ru (A.K.); belyaev@igc.irk.ru (V.B.) \\ * Correspondence: skuzovatov@igc.irk.ru
}

Received: 3 April 2020; Accepted: 27 April 2020; Published: 29 April 2020

check for updates

\begin{abstract}
This study reports on mineral and bulk rock compositions of metaperidotites from the Alag Khadny accretionary complex in SW Mongolia, to reveal their nature and relationships with associated eclogites. The peridotites preserved original porphyroclastic textures and are composed of olivine, orthopyroxene relics, $\mathrm{Cr}$-spinel, interstitial (not residual) clinopyroxene, and secondary chlorite, tremolite, olivine, $\mathrm{Cr}$-magnetite, clinopyroxene, and antigorite. Cr-spinel has $\mathrm{Cr} \#$ of $0.3-0.5$, and primary olivine shows $\mathrm{Mg} \#$ of $0.90-0.92$. The pyroxenes are high-magnesian with low $\mathrm{Al}_{2} \mathrm{O}_{3}$ and $\mathrm{Cr}_{2} \mathrm{O}_{3}$. The bulk rocks have $\mathrm{U}$-shaped normalized trace-element patterns with enrichment in LILE, $\mathrm{L}-\mathrm{MREE}$ relative to $\mathrm{HREE}$, and weak $\mathrm{Pb}-\mathrm{Sr}$ peaks and $\mathrm{Nb}-\mathrm{Zr}-\mathrm{Hf}$ minima. Interstitial clinopyroxene exhibits $\mathrm{V}$ - and U-shaped normalized REE patterns with $(\mathrm{La} / \mathrm{Yb})_{\mathrm{N}}>1(\mathrm{Yb}=1.2-3$ of chondritic values) and enrichment in fluid-mobile elements and Zr. HREE abundances of clinopyroxene can be simulated by $23-26 \%$ partial melting of depleted mantle starting at garnet-facies (6-8\%) depths, followed by hydrous or anhydrous melting at spinel-facies depths L-MREE characteristics of clinopyroxenes can be simulated by further interaction of harzburgites with an island-arc basaltic melt in a supra-subduction environment. The association of hydrous secondary minerals in the Alag Khadny peridotites suggests their retrograde metamorphism at 1.6-2.0 GPa and $640-720^{\circ} \mathrm{C}$, similar to P-T conditions reported earlier for the spatially associated eclogites. This supports metamorphism of the Alag Khadny peridotites in a mantle wedge, followed by joint exhumation of peridotites and eclogites. Given the findings above and implying the regional geological background, we advocate for a sequential Neoproterozoic evolution the Alag Khadny harzburgites from (1) their formation by decompression partial melting in an Early Neoproterozoic or older spreading center of a mid-ocean or back-arc setting, and (2) refertilization by supra-subduction melts, followed by (3) Late Neoproterozoic-Early Cambrian hydrous-fluid metamorphism and juxtaposition with eclogites.
\end{abstract}

Keywords: Central Asian Orogenic Belt; mantle wedge; peridotites; partial melting; refertilization; fluids; subduction; metamorphism

\section{Introduction}

Serpentinized peridotites are crucial for recycling of volatiles and fluid-mobile elements (FME) in subduction zones [1-4]. Of a specific interest are ultramafic rocks, which constitute the subducted tectonites or mélange between a slab and a mantle wedge [5-8], or represent the fragments of hydrated supra-subduction mantle [9-11]. Peridotites of a mantle wedge witnessed various petrologic processes such as metamorphism [12,13], modification by subduction fluids [14], and upward migration of supra-subduction zone (SSZ) melts $[15,16]$. Mantle-wedge peridotites possess a range of mineral 
and chemical compositions, as well as associated rock types, depending on nature of subducting lithosphere, i.e., oceanic or continental [17].

In many cases, serpentinites compose large-scale deformation zones, which host less deformed blocks of the oceanic mantle, mafic crust, and metasediments $[9,18]$. Moreover, it was demonstrated multiple times that the presence of serpentinized peridotites may facilitate processes of exhumation of high-pressure (HP) rock, such as eclogites and blueschists $[9,19,20]$. Recently, a new Neoproterozoic-Early Cambrian Alag Khadny (AK) high-pressure assemblage of eclogites, metasediments and metagranitoids $\left({ }^{40} \mathrm{Ar}-{ }^{39} \mathrm{Ar}\right.$, phengite, 537-548 Ma) [21-23] was recognized in the Early Caledonian accretionary complex of SW Mongolia located southwest from the Dzabkhan-Baidrag microcontinent [24]. Based on geochemical and isotopic signatures of eclogites, the formation of rock protoliths within an oceanic slab [22] and subducted passive margin [23,25] has been argued. Southwards from the AK, where eclogites, HP metasediments, and orthogneisses display partially coherent subduction record [26], there are juxtaposed units of carbonate rocks, amphibolites, and a massive block of serpentinized peridotites. The nature of mantle rocks, their position in the mentioned Neoproterozoic-Early Paleozoic accretionary system, and possible coherence of metamorphic history with that of HP unit have not been identified so far. Here, the original data of mineralogy, whole-rock, and in situ geochemistry of these rocks are provided to constrain the origin (oceanic vs. subcontinental lithospheric mantle), as well as chemical and metamorphic history of the AK peridotites.

\section{Geological Background}

Formation and evolution of the Central Asian Orogenic Belt (CAOB), one of the largest orogenic belts built on the Earth, associates with continuous and significant reworking of the preexisting ancient continental crust [27,28]. Particularly, the central segment of the Central Asian Orogenic Belt in SW Mongolia is composed of microcontinents with the Precambrian basement surrounded by Neoproterozoic to Paleozoic island-arc and accretionary terrains formed at convergent plate margins (Figure 1a). The Neoproterozoic Dzabkhan microcontinent is bounded from the west by Dariv and Khantaishir supra-subduction ophiolites [3,4], which mark the transition to the Lake Zone of island-arc origin [29].

The fieldwork area is located in the Zamtyn range, $20 \mathrm{~km}$ to NE from the Chandman village. The original description of the detailed geological structure of the area were provided by Štípská et al. [22] and in the original mapping results of Hanžl and Aichler [30]. The basement there is presumably made of high-grade rocks of the Zamtyn Nuruu crystalline complex (ZNC) that yield from the Neoproterozoic to Early Cambrian zircon ages (948-941 Ma) [25,30,31]. The ZNC is tectonically overlain by the Early Cambrian volcano-sedimentary and carbonate cover of the Tsakhir Uul formation [31]. Mafic eclogites composed of garnet + omphacite + amphibole + rutile \pm phengite \pm quartz \pm epidote/clinozoisite were originally distinguished as separate boudins up to hundreds of meters across in metasediments and carbonate rocks [22,23] and are strictly confined to the unit of orthogneisses and metapelites (Alag Khadny crystalline complex, AK) [22,23]. HP assemblage of the AK was originally considered an accretionary complex of an Early Cambrian oceanic subduction zone over-thrusting the crystalline basement [21], based on transitional mid-ocean ridge basalt (T-MORB) chemistry of eclogites. A few later models suggest the formation of sedimentary and igneous protoliths for metamorphic rocks in a continental margin setting [25], with further evolution to the Early Caledonian (540-530 Ma) subduction-accretion stage. The ages of eclogites (phengite Ar-Ar, $543 \mathrm{Ma}$ ) and metapelites (same method, $537 \mathrm{Ma}$ ) [22] are similar to zircon $\mathrm{U}-\mathrm{Pb}$ date for orthogneisses (538 Ma intercept of discordia) [25].

The present study focuses on mantle rocks of the Alag Khadny complex, composing a large body with length of $8 \mathrm{~km}$ and width up to $1.5 \mathrm{~km}$ (Figure $1 \mathrm{~b}$ ). This ultramafic body has tectonic contacts with metavolcanic and metasedimentary rocks of the Maykhan Tsakhir Formation. The ultramafic rocks are represented by serpentinites and metaperidotites, which were characterized in terms of geology and petrography [30], without systematic geochemical and petrologic studies. Previous workers suggested that the ultramafic rocks in this area could be a structural continuation of the Khantaishir 
ophiolite located $\sim 140-180 \mathrm{~km}$ to the NW [32,33]. After detailed geological works at Zamtyn Nuruu Range, serpentinized peridotites were included into the Alag Khadny crystalline complex of eclogites, amphibolites, and metasediments described in this area [22,25,30,34]. Therefore, these peridotites are confined to the Alag Khadny accretionary complex and are not spatially associated to other members of an ophiolite sequence such as gabbro, sheeted dikes, or pillow lavas. It should be noted, however, that according to our field observations, dikes (width from $10 \mathrm{~cm}$ to $1.5 \mathrm{~m}$ ) of basaltic to andesitic composition cut the Alag Khadny peridotites (Figure 1b; Supplementary Materials Figure S1).
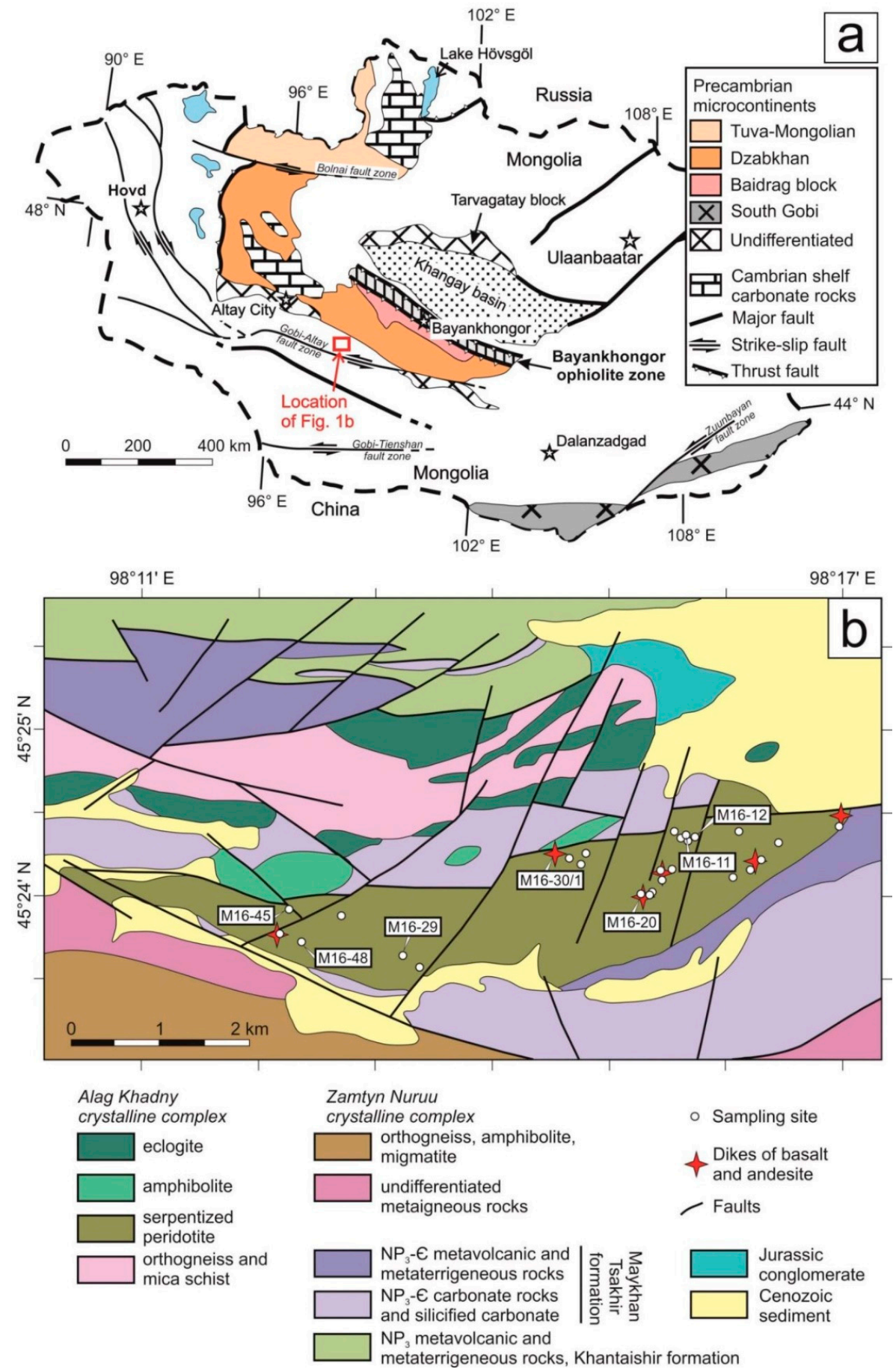

Figure 1. Simplified tectonic map of Mongolia, with the location of the Alag Khadny complex [35] (a), and a geological scheme of the study area (b), modified after $[25,30]$. 


\section{Materials and Methods}

Samples of the least serpentinized metaperidotites were used for the current mineralogical and geochemical studies. Petrographic observations of the peridotite samples were compiled by using optical microscopy and backscattered-electron imaging. Electron-probe microanalysis (EPMA) of minerals was done with a JEOL Superprobe JXA-8200 (JEOL Ltd., Tokyo, Japan) electron microprobe at an accelerating voltage of $20 \mathrm{kV}$, beam current of $20 \mathrm{nA}$, and $1 \mu \mathrm{m}$ beam size. Olivine, diopside, pyrope, orthoclase, albite, ilmenite, chromite and Mn-garnet, nickel ferrite, and sphalerite were used as calibration standards.

Bulk-rock major-element contents were obtained by X-ray fluorescence (XRF) method, using S8 Tiger spectrometer (Bruker AXS, Karlsruhe, Germany), according to the technique of [36]. Ti was determined by XRF on the S4 Pioneer spectrometer (Bruker AXS) with Rh-anode tube at $40 \mathrm{kV}$ accelerating voltage and $50 \mathrm{~mA}$ current. Trace-element concentrations were obtained by inductively coupled mass spectrometry (ICP-MS), using a Perkin Elmer NexION 300D mass-spectrometer. The above analyses were done at the Centre of Isotope-Geochemical Investigations, Institute of Geochemistry SB RAS (IGC; Irkutsk, Russia).

Trace-element concentrations in the selected small ( 100 $\mu \mathrm{m})$ clinopyroxenes (samples M16-45, 48) were determined by using Cameca ims-4f secondary-ion mass-spectrometer (SIMS), at the Yaroslavl Branch of the Institute of Physics and Technology RAS (Yaroslavl, Russia). Measurement conditions included a focused primary $\mathrm{O}^{2-}$ ion beam with the energy of $14.5 \mathrm{keV}$, spot diameter of $20 \mu \mathrm{m}$, and primary ion current of $8 \mathrm{nA}$. Each measurement included 5 cycles of signal acquisition, and the total signal accumulation time for each point was about $50 \mathrm{~min}$. The obtained intensity values were normalized to ${ }^{30} \mathrm{Si}$, while the reference $\mathrm{SiO}_{2}$ content was set according to the results of EPMA studies. Corrections for $\mathrm{Gd}, \mathrm{Yb}, \mathrm{Eu}$, and Er were calculated by method of [37]. Larger grains of clinopyroxene (samples M16-11, 12, and 29) were analyzed by laser-ablation inductively coupled mass spectrometry (LA-ICP-MS) with an NWR-213 laser ablation system connected to a Perkin Elmer NexION 300D mass spectrometer housed at IGC (Irkutsk, Russia). The laser operated at energy density $6.5 \mathrm{~J} / \mathrm{cm}^{2}$, $10 \mathrm{~Hz}$ repetition rate, and beam size of $100 \mu \mathrm{m}$. Acquisition time was $20 \mathrm{~s}$ for background and $60 \mathrm{~s}$ for sample signal during ablation. The values of the cooling, plasma-forming, and additional Ar flows were 16.0, 1.0, and $0.4 \mathrm{~L} / \mathrm{min}$, respectively. Helium with a purity of 4.5 and a flow rate of $0.6 \mathrm{~L} / \mathrm{min}$ was used as the carrier gas. The plasma energy was $1350 \mathrm{~W}$. The NIST SRM 612 glass was used for calibration, and USGS basaltic glasses BCR-2G and BIR-1G were analyzed as unknowns, to control the accuracy and reproducibility of measurements. Trace-element concentrations were calculated with the GLITTER (version 4.4.4) (www.es.mq.edu.au/gemoc/glitter), with ${ }^{29} \mathrm{Si}$ as an internal standard derived from EPMA $\mathrm{SiO}_{2}$ contents.

\section{Results}

\subsection{Petrography}

In metaperidotites, mineral association of olivine \pm orthopyroxene + clinopyroxene $+\mathrm{Cr}$-spinel + tremolite + chlorite + serpentine is present. Primary olivine porphyroclasts (Ol1) are large (up to $4 \mathrm{~mm}$ ). The rocks contain both large (up to $7 \mathrm{~mm}$ ) (Figure 2A,B,G) and small (up to $300 \mu \mathrm{m}$ ) (Figure 2B,D,F,L) pseudomorphs formed after orthopyroxene. The pseudomorphs are composed of tremolite + olivine3 + clinopyroxene $2+$ serpentine \pm Cr-magnetite (Figure 2E). Relics of orthopyroxene with clinopyroxene lamellae are found only within large pseudomorphs (Figure 2G). Ol3 from pseudomorphs has a size of 20-60 $\mu \mathrm{m}$ (Figure 2E). 

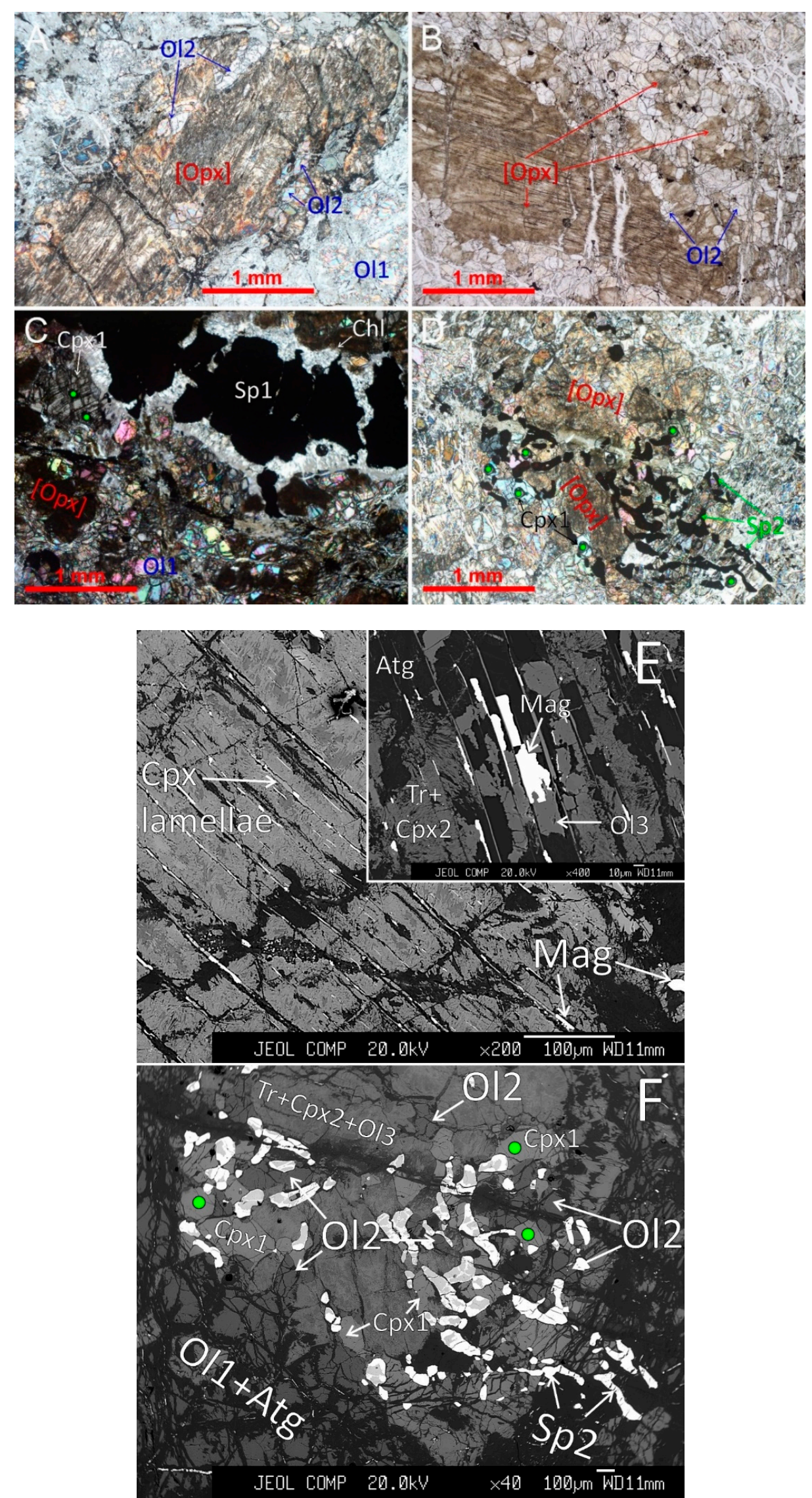

Figure 2. Cont. 


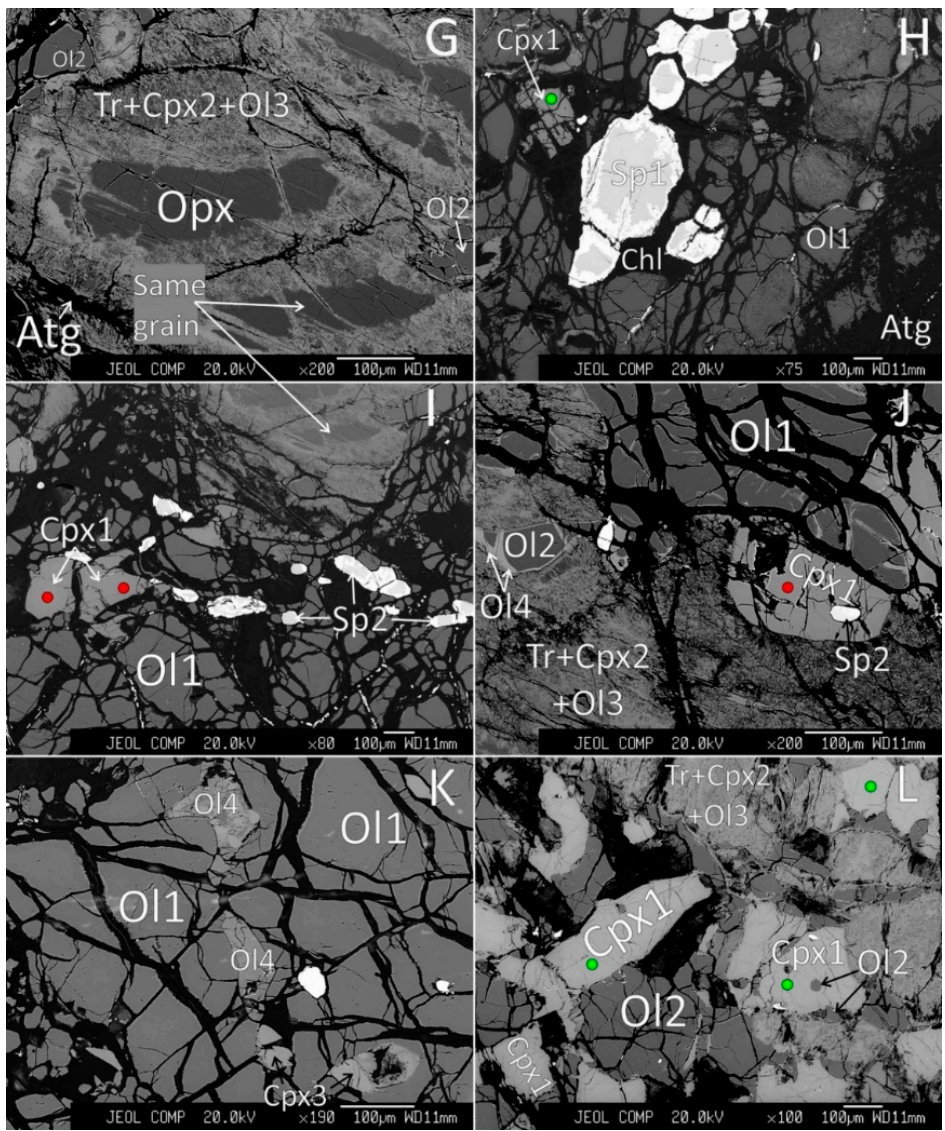

Figure 2. Optical (A-D) and backscattered electron (BSE) (E-L) photomicrographs of the Alag Khadny peridotites. (A) Sample M16-48, a pseudomorph after a large Opx porphyroclast with embayments filled with newly formed Ol2; (B) sample M16-29, a pseudomorph after an Opx porphyroclast with resorbed margin changing to the newly formed $\mathrm{O} 2 \mathrm{2}$ and medium-sized pseudomorphs after Opx (right); (C) sample M16-11, a porphyroclast of irregular-shaped Sp1 surrounded by a Chl rim; (D) sample M16-29, pseudomorphs after medium-sized Opx grains associated with newly formed O12, Cpx1, and vermicular Sp2. BSE photo of this area is shown in Figure 2F; (E) sample M16-29, a pseudomorph after a large Opx porphyroclast composed of Ol3, Atg, fibrous aggregate of $\mathrm{Tr}$, and $\mathrm{Cp} \times 2$ and oriented Cpx lamellae and Mag. The inset shows the pseudomorph after Opx at higher magnification; (F) sample M16-29, newly formed small grains of O12, Cpx1, and vermicular Sp2 associated with medium-sized pseudomorphs after Opx; (G) sample M16-45, relic of primary Opx with Cpx exsolutions partially replaced by pseudomorphic aggregates of $\mathrm{Tr}, \mathrm{Cpx3}, \mathrm{Ol3}$, and Atg; (H) sample M16-12, a holly-leaf porphyroclast of Sp1 with Cr-Mag rim and Chl corona around the spinel, interstitial irregular Cpx1, and small pseudomorphs after Opx in Ol1 matrix; (I) sample M16-45, the same Opx porphyroclast as in Figure 2G with interstitial grains of Cpx1 and vermicular Sp2 in Ol1 matrix; (J) sample M16-45, an interstitial grain of Cpx1 with inclusion of Sp2 at the edge of a large pseudomorph after Opx, replacement of $\mathrm{Ol1}$ and $\mathrm{Ol} 2$ by metamorphic O14; (K) sample M16-11, veinlet of O14 and Cpx3 crosscutting Ol1 matrix; (L) sample M16-11, numerous large grains of Cpx1 with inclusions of Ol2 and $\mathrm{Sp} 2$, associated with $\mathrm{O} 12$ and medium-sized pseudomorphs after Opx. Green dots are sites of LA-ICP-MS, and red dots are sites of SIMS analyses of Cpx, correspondingly. Sp1—spinel porphyroclasts; Sp2-newly formed vermicular and rounded spinel; Ol1—primary olivine; O12-newly crystallized olivine; $\mathrm{Ol} 3$ - secondary olivine associated with fibrous tremolite and $\mathrm{Cp} \times 2$ in pseudomorphs after Opx; Ol4—iron-rich olivine bands after Ol1 matrix; Opx—orthopyroxene; [Opx]—pseudomorphs after Opx; Cpx1-irregular newly formed clinopyroxene; Cpx2-metamorphic clinopyroxene associated with tremolite and $\mathrm{Ol} 3$ in pseudomorphs after Opx; Cpx3-secondary grains associated with Ol4; $\mathrm{Tr}$-tremolite; Atg—antigorite; Chl—chlorite; Mag-magnetite. 
Clinopyroxene (Cpx1) is represented by interstitial irregularly shaped grains with size from tens to hundreds of $\mu \mathrm{m}$ without exsolution lamellae. Cpx1 is often associated with small grains of olivine (Ol2) and spinel (Sp2) (Figure 2D,F,H,I). In the sample M16-11, clinopyroxene is abundant ( 7\%) compared to other samples; it has size up to $0.8 \mathrm{~mm}$ (Figure 2c) and contains inclusions of $\mathrm{Ol} 2 \mathrm{and} \mathrm{Sp2}$ (Figure 2L). This clinopyroxene does not have exsolution lamellae and is not a porphyroclast; therefore, we suggest its magmatic nature (Cpx1). Moreover, clinopyroxene in the Alag Khadny peridotites is found as exsolution lamellae within relic orthopyroxene (Figure 2G) and within large pseudomorphs after orthopyroxene (Figure 2E). Metamorphic clinopyroxene (Cpx2) composes fine needlelike crystals associated with tremolite and $\mathrm{Ol} 3$ in pseudomorphs after orthopyroxene (Figure 2E,G,L), and small grains in serpentine veinlets (Cpx3) after olivine. Cpx3 is often associated with iron-rich olivine (Ol4), which forms bands after Ol1 and Ol2 (Figure 2J,K).

Cr-spinel has a variety of grain sizes and shapes. Irregular-shaped or holly-leaf porphyroblasts of spinel (Sp1) with size up to $2 \mathrm{~mm}$ are located within interstitial space (Figure $2 \mathrm{C}, \mathrm{H}$ ). Smaller vermicular Sp2 (up to 100-300 $\mu \mathrm{m}$ ) forms intergrowth with Cpx1 and Ol2 (Figure 2D,F,I). Rounded crystals of $\mathrm{Sp} 2$ are small and appear in the interstitial space or as inclusions within O12 and Cpx1 (Figure 2G). Sp1 show homogeneous central parts surrounded by rims of Cr-magnetite. Sp2 either exhibits zoned appearance as Sp1 or is homogeneous and resembles rims of Sp1.

Chlorite occurs as aggregates around metamorphosed chromian spinel (Figure 2C,H). Moreover, chlorite is sometimes associated with tremolite and serpentine. Tremolite is present as fine needlelike crystals in pseudomorphs after orthopyroxene (Figure 2E,G,L). There are two generations of serpentine. Early serpentine occurs as needles or blades after tremolite, or as flake-like aggregates after Ol1. Late serpentine fills in the cracks within olivine and pseudomorphs after orthopyroxene.

The protoliths of the rocks were composed of olivine ( 70-85 vol. \%), orthopyroxene (15-25 vol. \%), Cr-spinel $(\sim 1 \%)$, and clinopyroxene ( 1-2\%; except for the sample M16-11 with $7 \%$ Cpx), thus corresponding to Cpx-poor hazrburgites. Since the rocks preserved their original textures, we further refer to them as to harzburgites or peridotites. Although the rocks suffered metamorphic transformations, they preserved original textures: porphyroclastic and, rarely, granular, which are typical for mantle peridotites [38]. The studied samples have textures suggestive of reactive porous flow [39]. The boundaries of former orthopyroxene generally display embayments filled with replacive Ol2 of smaller size (Figure 2A). This olivine often penetrates the former orthopyroxene along the cleavage (Figure 2B). The rocks contain separate aggregates of medium-sized grains of the former orthopyroxene with associated O12, Sp2, and Cpx1 (Figure 2D). These aggregates have size of few millimeters. Mineral association and vermicular shape of spinel make them similar to products of garnet decomposition, which occurs during transition from the Gr-facies to the Sp-facies of mantle peridotite. But, in the studied rocks the same mineral association is found next to resorbed margins of former orthopyroxene porphyroclasts (Figure 2B). Therefore, following [39], such aggregates could be interpreted as products of orthopyroxene porphyroclast interaction with melt. In this case, $\mathrm{Ol} 2, \mathrm{Sp} 2$ and $\mathrm{Cpx} 1$ represent newly formed minerals crystallized from percolated melt, and former medium-sized orthopyroxene are recrystallized remnants of the former orthopyroxene porphyroclasts.

\subsection{Mineral Compositions}

Central parts of Sp1 are homogeneous with Cr\# 0.3-0.5, Mg\# 0.65-0.5, and low $\mathrm{Fe}_{2} \mathrm{O}_{3}(1.6-4.6$ wt.\%), $\mathrm{TiO}_{2}(<0.1$ wt.\%), $\mathrm{MnO}(<0.3$ wt.\%), and $\mathrm{ZnO}(<0.4$ wt.\%) (Supplementary Table S1). Such a composition is common for primary spinels from residual mantle peridotites $[39,40]$. The studied Sp1 has Cr\# values correspond more to abyssal peridotites, although $\mathrm{Mg \#}$ is lower (Figure 3A). The rim is characterized by similar or lower $\mathrm{Cr}_{2} \mathrm{O}_{3}$; lower $\mathrm{MgO}$ and $\mathrm{Al}_{2} \mathrm{O}_{3}$; and higher $\mathrm{FeO}, \mathrm{Fe}_{2} \mathrm{O}_{3}, \mathrm{NiO}, \mathrm{TiO}_{2}, \mathrm{ZnO}$, and $\mathrm{MnO}$ compared to spinel core (Supplementary Table S1). The central parts of Sp2 generally have slightly lower Cr\# (Figure 3A) and Mg\# similar to Sp1. The rim of Sp2 exhibits composition identical to that of $\mathrm{Sp} 1 \mathrm{rim}$. The smallest grains of Sp2 often do not preserve primary cores. 


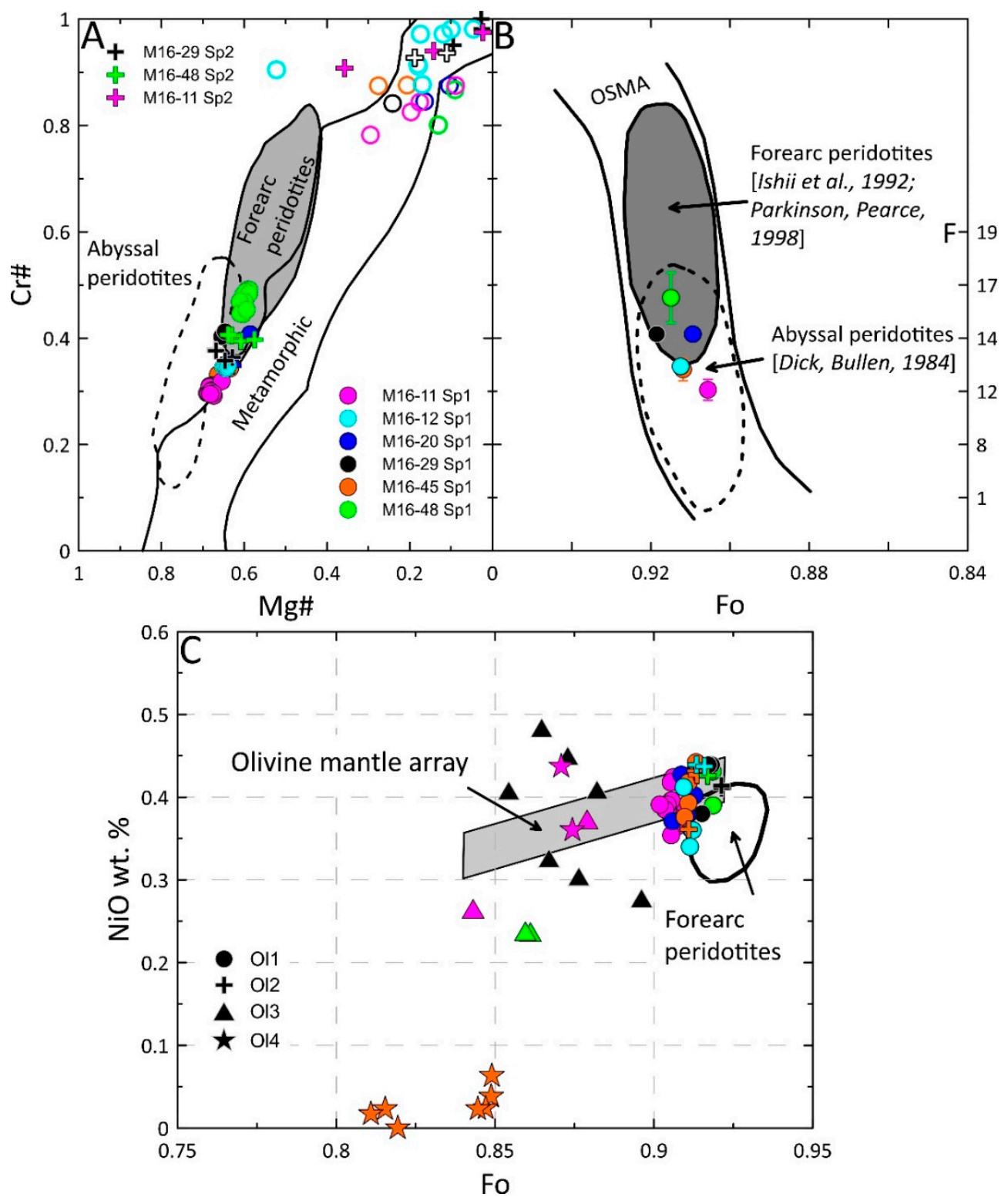

Figure 3. Compositional variations of spinel and olivine from the Alag Khadny peridotites. (A) $\mathrm{Cr} /(\mathrm{Cr}+$ $\mathrm{Al})$ vs. $\mathrm{Mg} /\left(\mathrm{Mg}+\mathrm{Fe}^{2+}\right)$ of spinel, $\mathrm{Sp} 1$ - spinel porphyroclasts, Sp2-newly formed spinel, filled symbols are cores, and empty symbols are rims; the abyssal peridotites field is from [40], forearc peridotites are from [41], and the metamorphic spinel field is from [42]. (B) $\mathrm{Cr} /(\mathrm{Cr}+\mathrm{Al})$ of spinel (Sp1) vs. Fo of olivine (Ol1). Olivine-spinel mantle array (OSMA) is after [43], F-Cr\# based melting degree after [44]. (C) $\mathrm{NiO}$ content vs. Fo of olivine, Ol1—primary olivine, Ol2 - newly formed olivine, Ol3-metamorphic olivine associated with tremolite, and O14-iron-rich olivine bands after Ol1 and O12. Different colors of the symbols are referred to different samples as shown in (A). The olivine mantle array is from [45], and the field of forearc peridotites is from [41].

Ol1 has Mg\# (0.90-0.92) and $\mathrm{NiO}$ (0.31-0.45 wt.\%) concentrations similar to residual mantle olivine, thus testifying to their primary nature (Figure 3C). Ol2, associated to Cpx1 and Sp2, has a composition identical to Ol1. Metamorphic $\mathrm{Ol} 3$ formed after orthopyroxene show $\mathrm{Mg \#}=0.84-0.89$ and $0.23-0.48 \mathrm{wt}$. $\%$ $\mathrm{NiO}$, and $\mathrm{Ol} 4$ formed after primary olivine have $\mathrm{Mg \#}=0.81-0.87$ and $0.02-0.44 \mathrm{wt} . \% \mathrm{NiO}$. On the $\mathrm{Mg \# Ol-Cr \# Sp} \mathrm{plot} \mathrm{(Figure} \mathrm{3B),} \mathrm{compositions} \mathrm{of} \mathrm{primary} \mathrm{olivines} \mathrm{and} \mathrm{Cr-spinel} \mathrm{cores} \mathrm{of} \mathrm{the} \mathrm{Alag}$ Khadny peridotites are located within the olivine-spinel mantle array and abyssal peridotite field, arguing for residual origin. 
Orthopyroxene is enstatite with high $\mathrm{Mg} \#(0.91-0.92)$; its $\mathrm{Al}_{2} \mathrm{O}_{3}$ and $\mathrm{Cr}_{2} \mathrm{O}_{3}$ contents are 1.7-2.6 wt.\% and 0.33-0.59 wt.\%, respectively (Supplementary Table S1). The compositions are within the overlap region between ultra-depleted abyssal and forearc peridotites in Figure 4A,C.
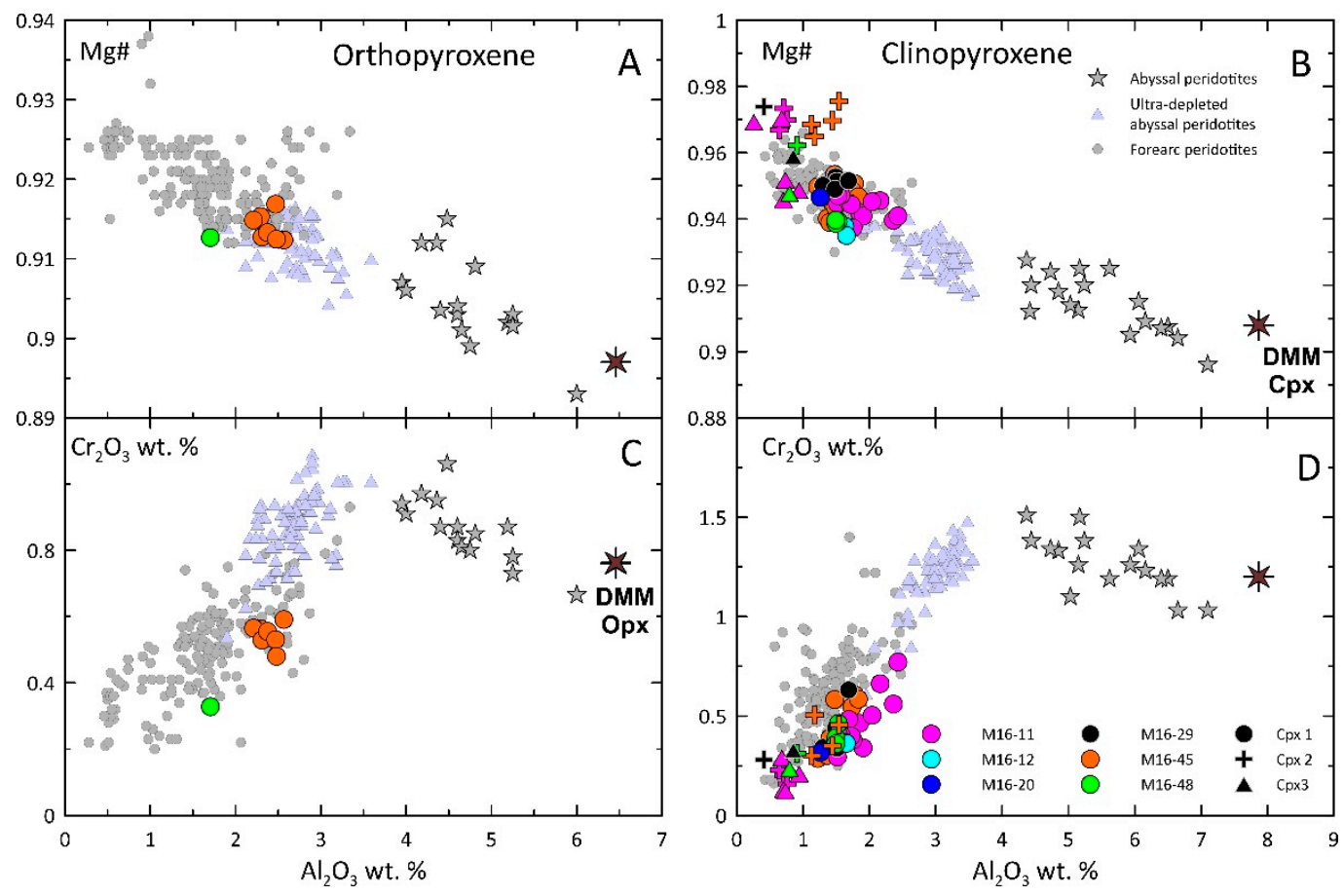

Figure 4. Major-element compositions of orthopyroxene $(\mathbf{A}, \mathbf{C})$ and clinopyroxene $(\mathbf{B}, \mathbf{D})$ from the Alag Khadny peridotites. Cpx1-interstitial clinopyroxene, Cpx2-metamorphic clinopyroxene in pseudomorphs after orthopyroxene, Cpx3-metamorphic clinopyroxene from serpentine veinlets after olivine. Different colors of the symbols are referred to different samples as shown in (D). Clinopyroxene and orthopyroxene compositions of Depleted MORB Mantle (DMM) are from [46], clinopyroxene analyses for the abyssal peridotites [47,48], ultra-depleted abyssal peridotites [39], and forearc peridotites [49] are shown for comparison.

Cpx1 has $\mathrm{Mg} \#=0.935-0.955,1.2-2.4$ wt. $\% \mathrm{Al}_{2} \mathrm{O}_{3}$, and 0.3-0.77 wt. $\% \mathrm{Cr}_{2} \mathrm{O}_{3}$ (Supplementary Table S1). Cores of large $\mathrm{Cpx}$ exhibit lower $\mathrm{Mg} \#$ and higher $\mathrm{Al}_{2} \mathrm{O}_{3}$ and $\mathrm{Cr}_{2} \mathrm{O}_{3}$ compared to their rims or small grains. $\mathrm{Na}_{2} \mathrm{O}$ abundances vary from b.d.l. to $0.16 \mathrm{wt} . \%$. $\mathrm{TiO}_{2}$ contents are very low (<b.d.1.), except for sample M16-11 (up to $0.19 \mathrm{wt} . \% \mathrm{TiO}_{2}$ ). Clinopyroxenes of the Alag Khadny metaperidotites resemble Cpx from forearc peridotites (Figure 4B,D). Metamorphic Cpx2 is more magnesian ( $\mathrm{Mg \#}=0.964-0.976)$; depleted in $\mathrm{Al}_{2} \mathrm{O}_{3}\left(0.4-1.54\right.$ wt.\%), $\mathrm{Cr}_{2} \mathrm{O}_{3}\left(0.16-0.5\right.$ wt.\%), and $\mathrm{TiO}_{2}$ (<b.d.1.); and contains higher $\mathrm{Na}_{2} \mathrm{O}(0.12-0.76 \mathrm{wt} . \%)$ abundances. Metamorphic Cpx3 is also more magnesian $(\mathrm{Mg} \#=0.945-0.970)$ and depleted in $\mathrm{Al}_{2} \mathrm{O}_{3}(<1 \mathrm{wt} . \%), \mathrm{Cr}_{2} \mathrm{O}_{3}(<0.3 \mathrm{wt} . \%), \mathrm{TiO}_{2}(<0.09$ wt. $\%)$, and $\mathrm{Na}_{2} \mathrm{O}(<0.08$ wt.\%).

Tremolites have high $\mathrm{Mg \#} \mathrm{(0.98)} \mathrm{and} \mathrm{appreciable} \mathrm{amounts} \mathrm{of} \mathrm{Al}_{2} \mathrm{O}_{3}$ (1.5-2.1wt.\%), $\mathrm{Na}_{2} \mathrm{O}$ (1.1-2.4 wt.\%), and $\mathrm{Cr}_{2} \mathrm{O}_{3}\left(0.31-0.52\right.$ wt.\%). Elevated $\mathrm{Al}_{2} \mathrm{O}_{3}$ and $\mathrm{Cr}_{2} \mathrm{O}_{3}$ could be inherited from precursor orthopyroxene. From $\mathrm{Na}_{2} \mathrm{O}$ and $\mathrm{SiO}_{2}$ relationships, tremolites have retrogressive origin [12]. Serpentine is a high-Mg\# (0.958-0.980) antigorite, while chlorite is clinochlore with $\mathrm{Mg}=0.972-0.98$ (Supplementary Table S1).

\subsection{Bulk-Rock Compositions}

The representative major-element compositions of peridotites are listed in Supplementary Table S2. Their bulk-rock Mg\# ranges from 0.89 to 0.92 and matches with their olivine composition $(\mathrm{Mg} \#=0.90-0.92)$. Peridotites are depleted in $\mathrm{A}_{2} \mathrm{O}_{3}(0.8-1.5$ wt.\% $), \mathrm{CaO}(0.3-3.1 \mathrm{wt} . \%), \mathrm{TiO}_{2}, \mathrm{Na}_{2} \mathrm{O}$, 
and $\mathrm{K}_{2} \mathrm{O}$ and enriched in $\mathrm{MgO}$, relative to primitive mantle (Figure 5). The rocks show a decrease in $\mathrm{Al}_{2} \mathrm{O}_{3}$ as $\mathrm{MgO}$ increases, as would be expected in residues after varying melting degrees. At the same time, abundances of $\mathrm{CaO}, \mathrm{FeOtot}$, and $\mathrm{SiO}_{2}$ show larger scatter and do not correlate with $\mathrm{MgO}$. A positive correlation of $\mathrm{CaO}$ with $\mathrm{Al}_{2} \mathrm{O}_{3}$ lacks, and the samples with similar $\mathrm{Al}_{2} \mathrm{O}_{3}$ contents show large scatter in $\mathrm{CaO}$. This indicates the apparent gain of $\mathrm{CaO}$ after partial melting of peridotites. On the $\mathrm{Al}_{2} \mathrm{O}_{3} / \mathrm{SiO}_{2}$ vs. $\mathrm{MgO} / \mathrm{SiO}_{2}$ diagram, the points of the Alag Khadny peridotites are located parallel to terrestrial array and along of "abyssal peridotite fit" line drawn through fresh samples (Figure 5E). The Alag Khadny peridotites could gain not more than $5 \% \mathrm{SiO}_{2}$ or could lost not more than $5 \% \mathrm{MgO}$ during alteration. Therefore, in terms of major elements (Figure 5), the Alag Khadny peridotites mostly preserved their residual signatures.
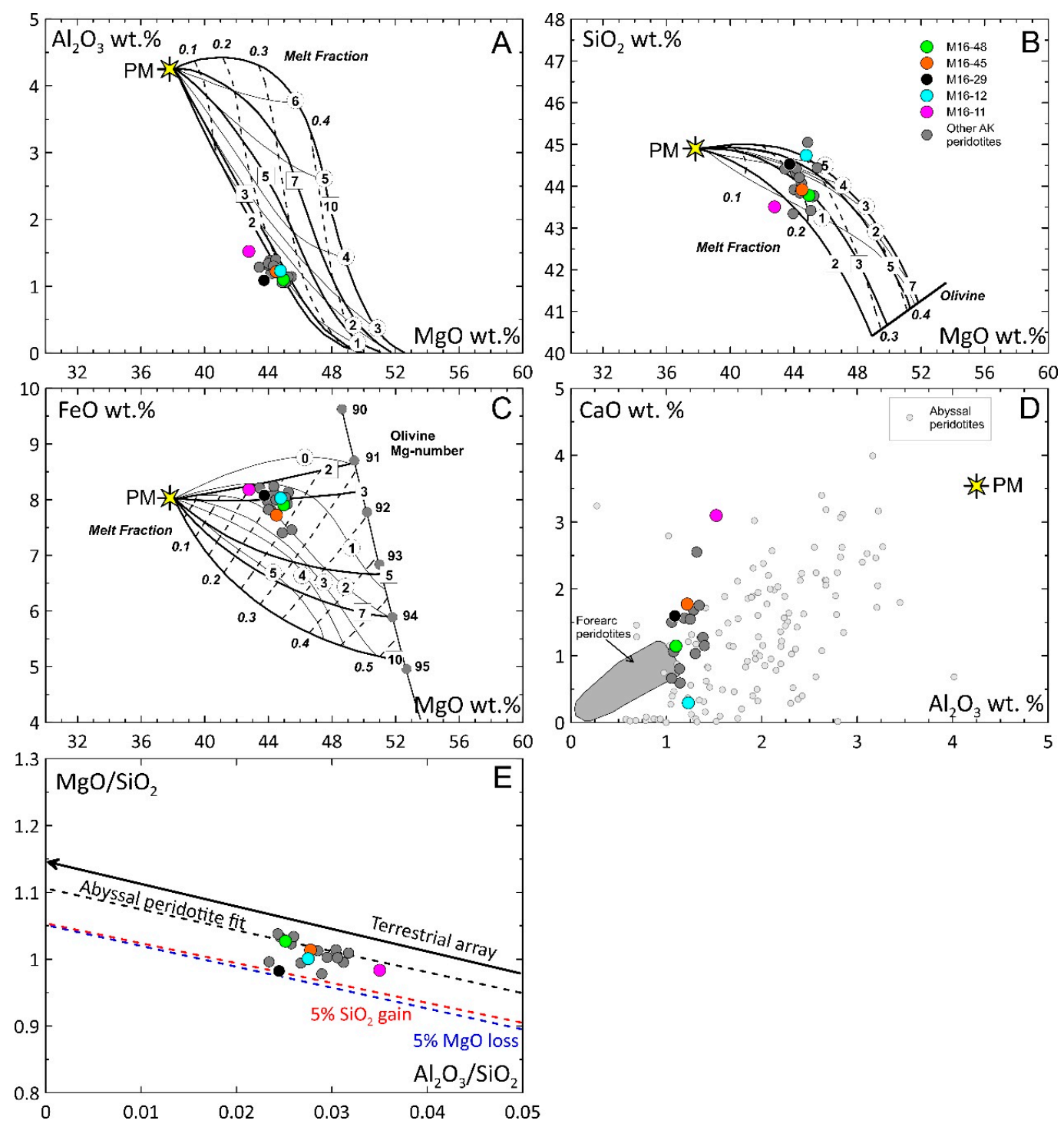

Figure 5. Variation diagrams for major oxides versus $\mathrm{MgO}(\mathbf{A}-\mathbf{D})$ and $\mathrm{MgO} / \mathrm{SiO}_{2}$ and $\mathrm{Al}_{2} \mathrm{O}_{3} / \mathrm{SiO}_{2}$ ratios (E) in the bulk-rock Alag Khadny peridotites. The model residue compositions formed by fractional melting are from [50], line labeled 90-95 in (C) shows mg-numbers of olivine; bold lines labeled with squares, initial melting pressures in GPa; light lines labeled with circles, final melting pressures; light dashed lines, melt fractions. Shaded area represents the composition field of forearc peridotites from [41], small gray dots-abyssal peridotites from [51], primitive mantle composition from [52]. Terrestrial array is from [53], abyssal peridotite fit line is from [54], and trends of $\mathrm{SiO}_{2}$ gain and $\mathrm{MgO}$ loss are from [55]. 
The Alag Khadny harzburgites have a U-shaped REE pattern with higher LREE relative to HREE, and low contents of $\mathrm{Yb}(0.08-0.13$ levels of primitive mantle). Positive Eu anomaly is present in some samples. The sample M16-11 exhibits low-slope REE with increase of normalized concentrations from $\mathrm{Lu}$ to La and higher $\mathrm{Yb}$ (0.3 levels of primitive mantle) (Figure 6). Abundances of HREE in most Alag Khadny peridotites overlap fields of both abyssal and forearc peridotites. Multi-element diagram shows enrichment of LILE, small $\mathrm{Pb}$ and $\mathrm{Sr}$ peaks, and weak $\mathrm{Nb}, \mathrm{Zr}$, and $\mathrm{Hf}$ depletion relative to $\mathrm{REE}$ (Figure 7).

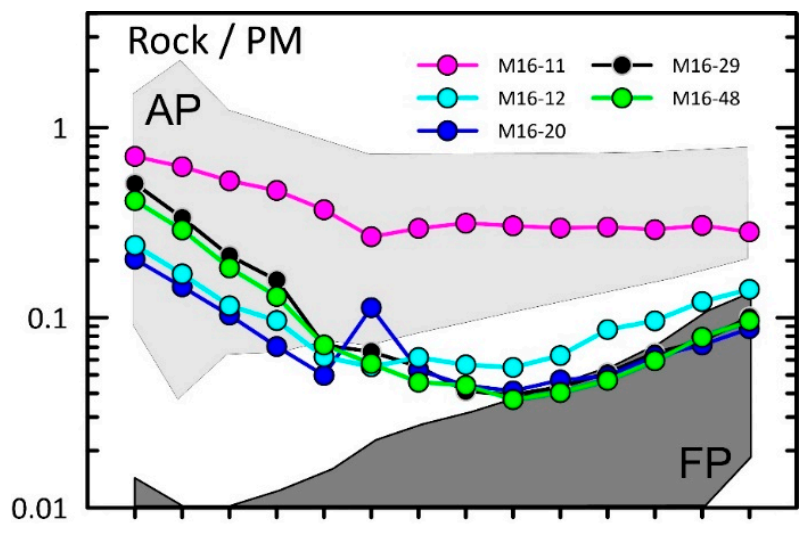

La Ce Pr Nd Sm Eu Gd Tb Dy Ho Er Tm Yb Lu

Figure 6. Primitive mantle-normalized [52] rare-earth-element patterns in the bulk-rock Alag Khadny peridotites. The background data are provided for forearc peridotites (FP) [41] and abyssal peridotites (AP) [51].

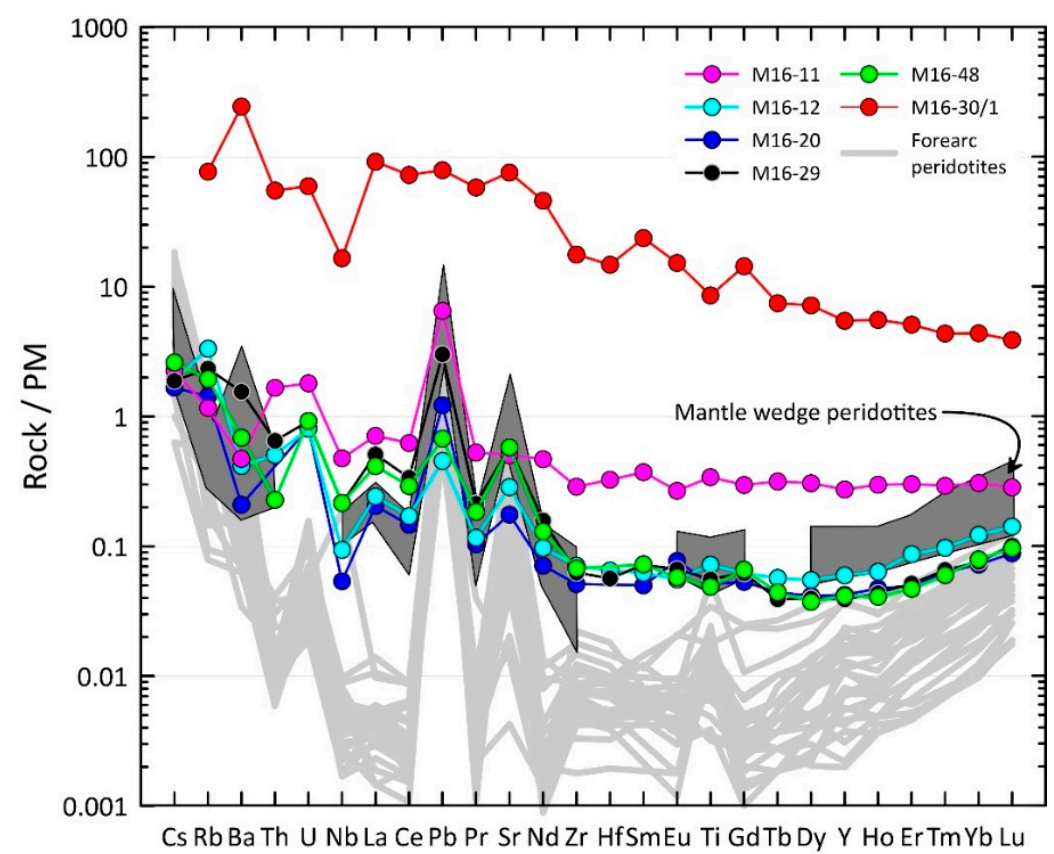

Figure 7. Primitive mantle-normalized [52] multi-element patterns in the bulk-rock Alag Khadny peridotites and in the dike of calc-alkaline basalt M16-30/1 cutting the peridotites. Forearc peridotites are from [41], and mantle-wedge peridotites are from [13].

\subsection{Trace Elements in Clinopyroxene}

Trace-element concentrations were analyzed in Cpx1. The results are presented in Supplementary Table S1. Trace-element concentrations show insignificant variations between and within grains; therefore, averaged compositions are shown on Figure 8. Clinopyroxenes from harzburgites (samples 
M16-45, 48, 12, and 29) have V- and U-shaped chondrite-normalized REE patterns with $(\mathrm{La} / \mathrm{Yb})_{\mathrm{N}}>1$. The REE shape is different from clinopyroxenes of supra-subduction and "normal" abyssal peridotites, and HREE contents are transitional between these peridotite types. Clinopyroxenes from sample M16-11 have different smooth REE patterns and resemble the bulk rock.

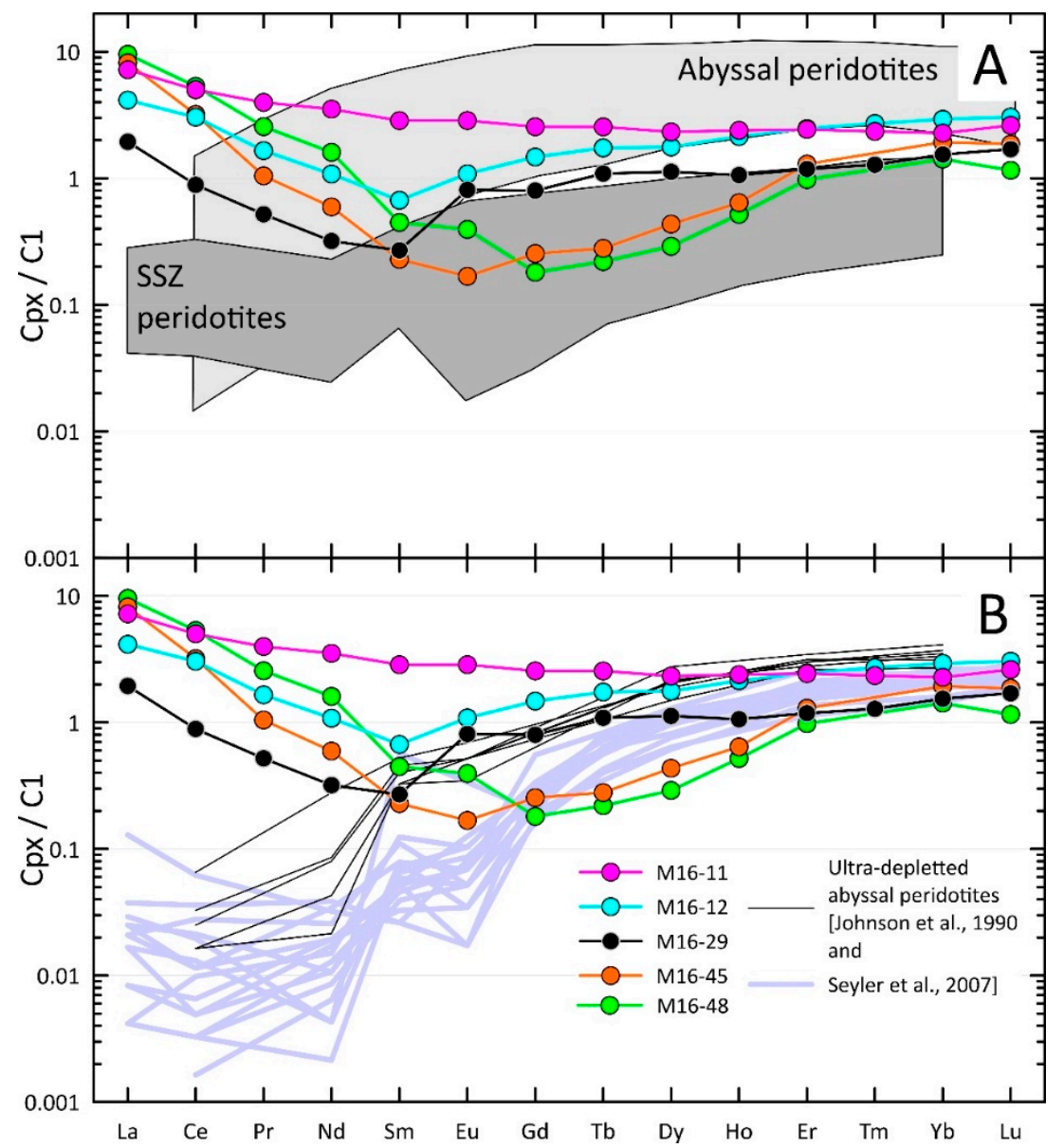

Figure 8. Chondrite-normalized [52] clinopyroxene rare-earth-element patterns for the Alag Khadny peridotites. (A) The field of abyssal-peridotite clinopyroxenes is after Johnson et al. [56]; supra-subduction zone (SSZ) peridotites are from [57,58]. (B) Ultra-depleted abyssal peridotites, [56]-black lines and [39]—violet lines.

\section{Discussion}

\subsection{The Origin of the Alag Khadny Peridotites}

Metamorphosed Alag Khadny harzburgites preserved their mantle porphyroclastic textures and relics of primary minerals represented by olivine, orthopyroxene, and $\mathrm{Cr}$-spinel cores. Compositions of these minerals correspond to those from oceanic lithospheric mantle peridotites (Figures 3 and 4). Abundances of major (Figure 5) and the least incompatible elements (HREE and Ti) (Figure 6) in the studied rocks also point to residual nature of the Alag Khadny peridotites. At the same time, some particular mineral compositions do not fit a simple melting model. The melting degree can be estimated from $C r \#$ of chromium spinel by the following formulation: $F=10 * \ln (\mathrm{Cr} \#)+24$ [48], where $F$ is the melting degree. In the Alag Khadny peridotites, $\mathrm{Cr}$-based $\mathrm{F}$ is $12-16.6 \%$ partial melting of Depleted MORB Mantle (DMM), which is well within the range of abyssal peridotites [51]. As the degree of partial melting increases, pyroxenes show an increase in $\mathrm{Mg} \#$ and decrease in $\mathrm{Al}_{2} \mathrm{O}_{3}, \mathrm{Na}_{2} \mathrm{O}_{\text {, }}$ and $\mathrm{TiO}_{2}$ abundances, while $\mathrm{Cr}_{2} \mathrm{O}_{3}$ first increases and then drops [59]. Clinopyroxenes of the studied rocks exhibit high $\mathrm{Mg} \#$ and low $\mathrm{Al}_{2} \mathrm{O}_{3}, \mathrm{Cr}_{2} \mathrm{O}_{3}, \mathrm{Na}_{2} \mathrm{O}$, and $\mathrm{TiO}_{2}$ contents (Figure 4), corresponding to 
minerals from supra-subduction peridotites, which form at higher melting degrees as compared to abyssal peridotites. Low $\mathrm{Al}_{2} \mathrm{O}_{3}$ and $\mathrm{Cr}_{2} \mathrm{O}_{3}$ of the Alag Khadny orthopyroxenes could result not only from subsolidus transformations during cooling and modification of the rocks by percolating melts, which dissolve orthopyroxenes [39], but also from high melting degrees. The observed inconsistency between compositions of spinel and the other minerals can be explained if the residual harzburgites represent products of partial melting started in the garnet stability field. In this case, spinel appears only after phase transition of garnet; therefore, $\mathrm{Cr} \#$ of the spinel does not reflect total melting degrees, but only indicates the spinel-facies' melting degree [48].

Variations in major-element compositions (specifically $\mathrm{MgO}, \mathrm{FeO}, \mathrm{SiO}_{2}$, and $\mathrm{Al}_{2} \mathrm{O}_{3}$ ) in the most Alag Khadny harzburgites show that they could be residues of $\sim 20 \%$ of fractional melting, which could start at $\sim 3 \mathrm{GPa}$ (i.e., in garnet-facies), according to petrogenetic grid of [50] (Figure 5). Low abundances of the least incompatible elements (Ti and HREE) in the bulk rocks also indicate higher melting degrees compared to $\mathrm{F}$ calculated from Cr-spinel composition.

Moreover, at the spinel-based melting degrees, the rocks should contain residual clinopyroxene. The Alag Khadny harzburgites contain no porphyroclastic clinopyroxene, and their Cpx1 is interstitial. In addition, the Alag Khadny harzburgites are characterized by the presence of newly formed Ol2 and $\mathrm{Sp} 2$. According to petrographic observations, the studied rocks could be interpreted as products of melt/rock transformation according to the following reaction: Opx $+\mathrm{L} 1 \rightarrow \mathrm{Ol} 2+\mathrm{Cpx} 1+\mathrm{Sp} 2+\mathrm{L} 2$. Interstitial clinopyroxene is interpreted commonly as a product of crystallization from melt. The melt is considered to be either incompletely extracted during the melting [39], or percolating incremental or aggregated melt generated at deeper levels [60], or an exotic melt refertilizing peridotites after their melting is completed [39]. Cpx1 evidently has major-element composition of magmatic clinopyroxene and is different from metamorphic $\mathrm{Cp} \times 2$ and $\mathrm{Cp} \times 3$ (Figure 4). Cpx1 exhibit HREE level and distribution close to that of clinopyroxene from the most depleted abyssal peridotites formed in mid-ocean ridges, often near hotspots $[39,48,56]$. These studies demonstrated that low MREE/HREE ratio in Cpx cannot be explained by the melting in spinel-facies only; thus, a previous melting in the garnet facies is needed to account for the observed Cpx composition. By analogy with the most-depleted abyssal harzburgites, the Alag Khadny peridotites could experience initial melting at the garnet-facies' depths. We suggest that, in the Alag Khadny harzburgites, Cpx1 crystallized from percolating incremental or aggregated melts generated in the mantle column at deeper levels, immediately after final stages of melting. The only exception from the above inferences is the sample M16-11. Compared to the other samples, M16-11 contains higher proportion of Cpx1, which is large and often contains inclusions of olivine. In terms of major-element composition, Cpx1 from the sample M16-11 resembles Cpx1 from the other Alag Khadny harzburgites, except for higher $\mathrm{TiO}_{2}$ in the former. At the same time, REE patterns of Cpx1 are strongly different and do not fit compositions of residual clinopyroxenes. Therefore, we suggest that formation of Cpx1 in sample M16-11 could be related to crystallization from an exotic melt during refertilization event after partial melting.

The Alag Khadny peridotites are enriched in both fluid-mobile elements (LILE), and fluid-immobile LREE, MREE, and HFSE (Figure 7), as compared to possible residues after melting inferred from HREE pattern. The rocks have geochemical signatures of mantle-wedge peridotites [61,62]. The Alag Khadny peridotites are more enriched in medium-incompatible elements (such as L-MREE, and HFSE) compared to, for example, metaperidotites of the Happo-O'ne massif, which are interpreted as products of mantle-wedge transformation by suprasubduction fluids [13]. Clinopyroxenes are also enriched in highly and medium-incompatible elements (Figures 8 and 9). In sample M16-11, the enrichment results in considerable change of trace-element patterns and even elevated abundances of the least incompatible elements. The studied rocks exhibit not only a gain of LILE (mobile in hydrous fluids), but they also demonstrate an increase in generally fluid-immobile HFSE, LREE, and MREE relative to HREE, and these characteristics should evidently result from a melt affecting the rock composition [41]. 


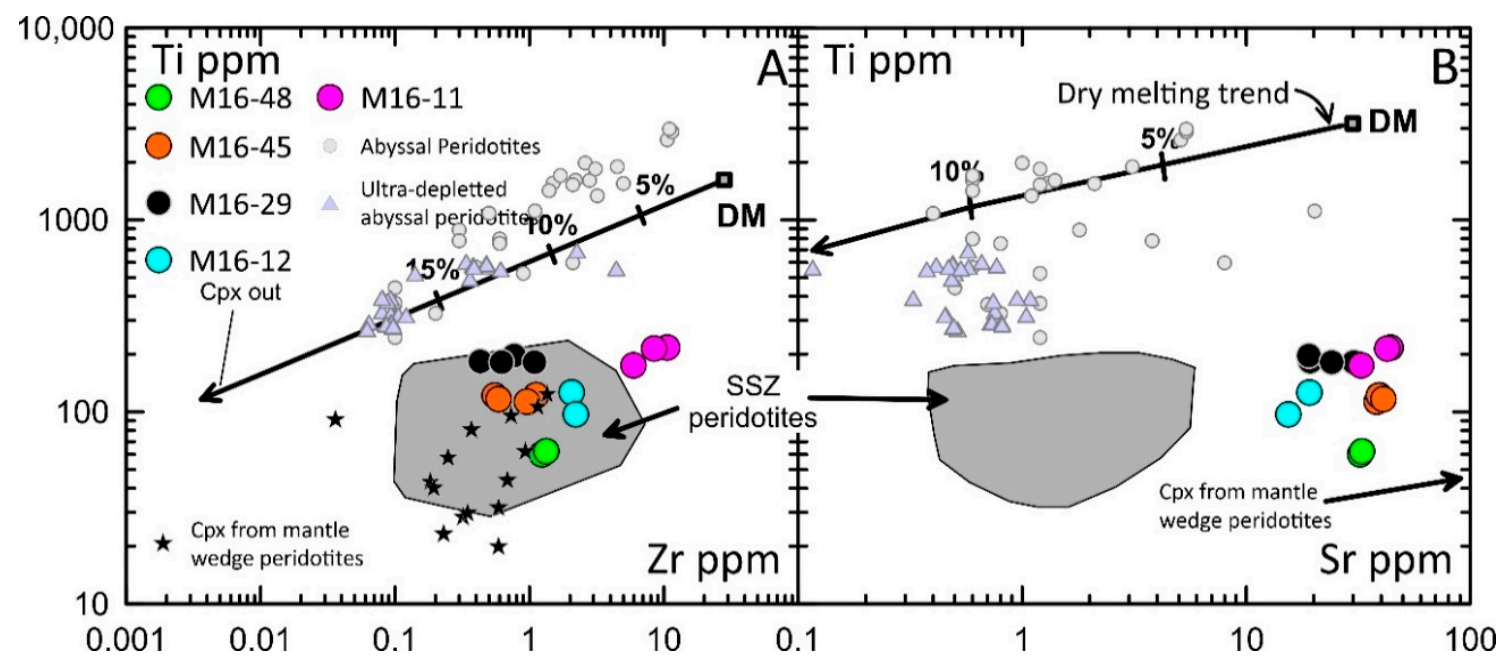

Figure 9. $\mathrm{Ti}, \mathrm{Zr}(\mathbf{A})$, and $\mathrm{Sr}(\mathbf{B})(\mathrm{ppm})$ abundances in clinopyroxenes. Fields of SSZ peridotite clinopyroxene from [57,58,63], clinopyroxene in abyssal peridotites [56] and ultra-depleted abyssal peridotites from [39], and clinopyroxene in mantle-wedge peridotites [13] are used for comparison. Black line-DM dry melting trend at polybaric fractional melting in spinel facies after [57].

The geochemical signatures described above can be found in peridotites formed after open-system melting, or in lithospheric mantle peridotites experienced melt/rock interaction. A distinctive feature of the open-system melting is a positive correlation between enrichment in incompatible elements and melting degree [64]. As Figure 8 shows, clinopyroxenes of the studied samples have similar $\mathrm{Yb}$ contents but different levels of LREE. It is more possible, hence, that deviations in bulk-rock and clinopyroxene compositions are related to melt-induced refertilization of the Alag Khadny peridotites, which took place after melting.

The studies have shown that the mantle-wedge peridotites can be affected by subduction-related melts, such as boninties, island-arc tholeiites, and slab melts $[65,66]$. The Alag Khadny peridotites are cut by the dikes of calc-alkaline basalts to andesites (Supplementary Table S2). They have trace-element characteristics of island-arc lavas, such as relative Th and LREE enrichment and depletion in HFSE (Figure 7). From a relatively high level of the most incompatible elements, the dikes are different from volcanics of frontal parts of island arcs and rather similar to rear-arc lavas [67]. It is therefore possible that the observed bulk-rock and clinopyroxene composition of Alag Khadny peridotites could result from percolation of similar melts.

The studied harzburgites are characterized by enrichment in fluid-mobile elements (FME). The Alag Khadny clinopyroxenes have higher B and, to a lesser extent, Li abundances compared to interstitial Cpx of abyssal peridotites (Figure 10). Comparable B and Li contents are found in Cpx from peridotites of the Coast Range ophiolite interpreted as products of hydrous melting with flux of a subduction component [14], as well as in Cpx from the Happo-O'ne massif peridotites originated from mantle wedge transformed by suprasubduction fluids [13]. Elevated abundances of Li and B in Cpx of the Alag Khadny peridotites can be interpreted from their formation as a result of hydrous melting, or modification by a suprasubduction fluid. On the other hand, interstitial clinopyroxenes of abyssal peridotites also exhibit considerable concentrations of Li and B [68] (Figure 10), which might indicate input of these elements from percolated melts. 


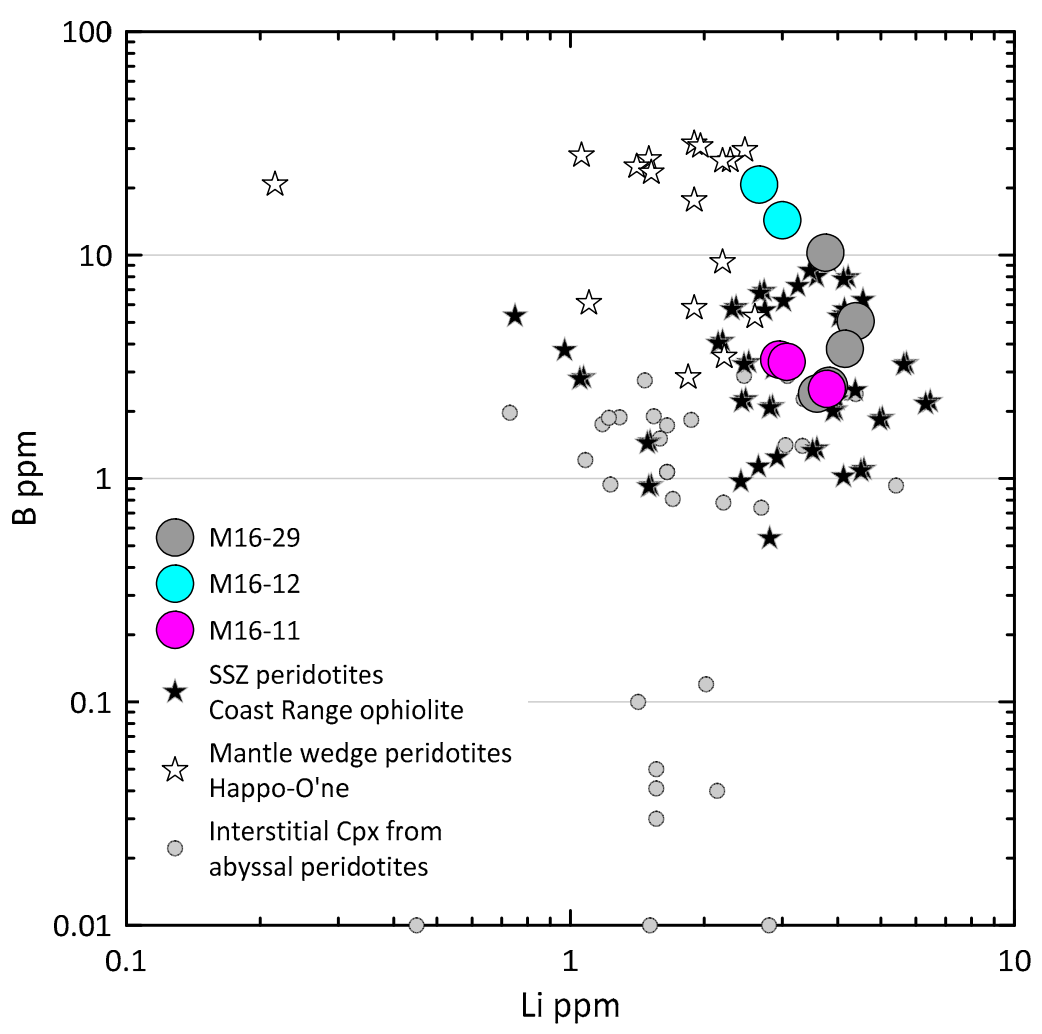

Figure 10. B vs. Li diagram for clinopyroxenes from Alag Khadny peridotites. Interstitial clinopyroxenes from abyssal peridotites [68], clinopyroxenes of SSZ peridotites from Coast Range ophiolite [14], and Happo-O'ne mantle wedge peridotites [13] transformed by suprasubduction fluids are shown for comparison.

Thus, geochemistry of the Alag Khadny harzburgites provide evidence for their formation as a result of (1) partial melting, which started in garnet facies, and (2) melt/peridotite interaction.

\subsection{Modeling of Partial Melting and Refertilization}

Conditions of the partial melting can be estimated from HREE patterns of newly formed clinopyroxenes [39], while the composition of a refertilizing melt is inferred from LREE distribution. It follows from the evidence that, after interaction of depleted peridotite with a melt (at low melt/peridotite ratio), the abundances of the lowest incompatible HREE in clinopyroxene would reflect the composition of residue [69,70]. In this process, highly incompatible elements such as LREE are controlled by the porosity of rocks and the composition of percolating melt, which result in LREE enrichment both in peridotite and its clinopyroxene.

We modeled the two formation stages of the Alag Khadny harzburgite modeling parameters are given in Supplementary Table S3: (1) anhydrous and hydrous melting, followed by (2) interaction with a melt. The non-modal dynamic melting model [71] was utilized. The melting process started in the garnet facies and proceeded in the spinel facies. The calculation of a mode at garnet-spinel transition was done according to equation of Johnson et al. [56]. The starting trace element and modal composition, melting reactions, and partition coefficients were the same as in $[48,60]$. The PETROMODELER spreadsheet program [72] was used for calculations. The modeling results of anhydrous and hydrous melting are shown on Figure 11. Simulation of 6-8\% melting in garnet facies, followed by $15-19 \%$ anhydrous melting in the spinel facies can reproduce HREE abundances in clinopyroxenes of the studied samples. After simulation of partial melting for the sample M16-12 (7\% of Grt-facies $+16 \%$ Sp-facies) the rock contained $0.3 \%$ clinopyroxene, whose composition was calculated according to [56]. To model the other samples, melting up to exhaustion of clinopyroxene was required, then $0.5 \%$ of clinopyroxene 
was added, and the modal composition of residue was recalculated to resemble the trace-element the composition of clinopyroxene. The estimated total melting degree for the Alag Khadny harzburgites is $23-25 \%$.

Experimental studies [73] found that, during hydrous melting, clinopyroxene is less consumed and is longer preserved in the residue compared to anhydrous melting. The modeling of mantle partial melting in the spinel-facies [57] demonstrated that clinopyroxene is consumed in the residual peridotite at $\sim 23 \%$ of anhydrous melting and $\sim 29 \%$ of hydrous melting. Our model for the Alag Khadny peridotites suggests $5-8 \%$ melting in the garnet-facies. Therefore, the difference in melting degree is only $1-2 \%$ between hydrous and anhydrous melting in the spinel-facies before clinopyroxene is consumed. Thus, melting in the garnet facies followed by hydrous melting in the spinel facies also closely reproduces HREE pattern observed in clinopyroxene of the Alag Khadny peridotites (Figure 11).

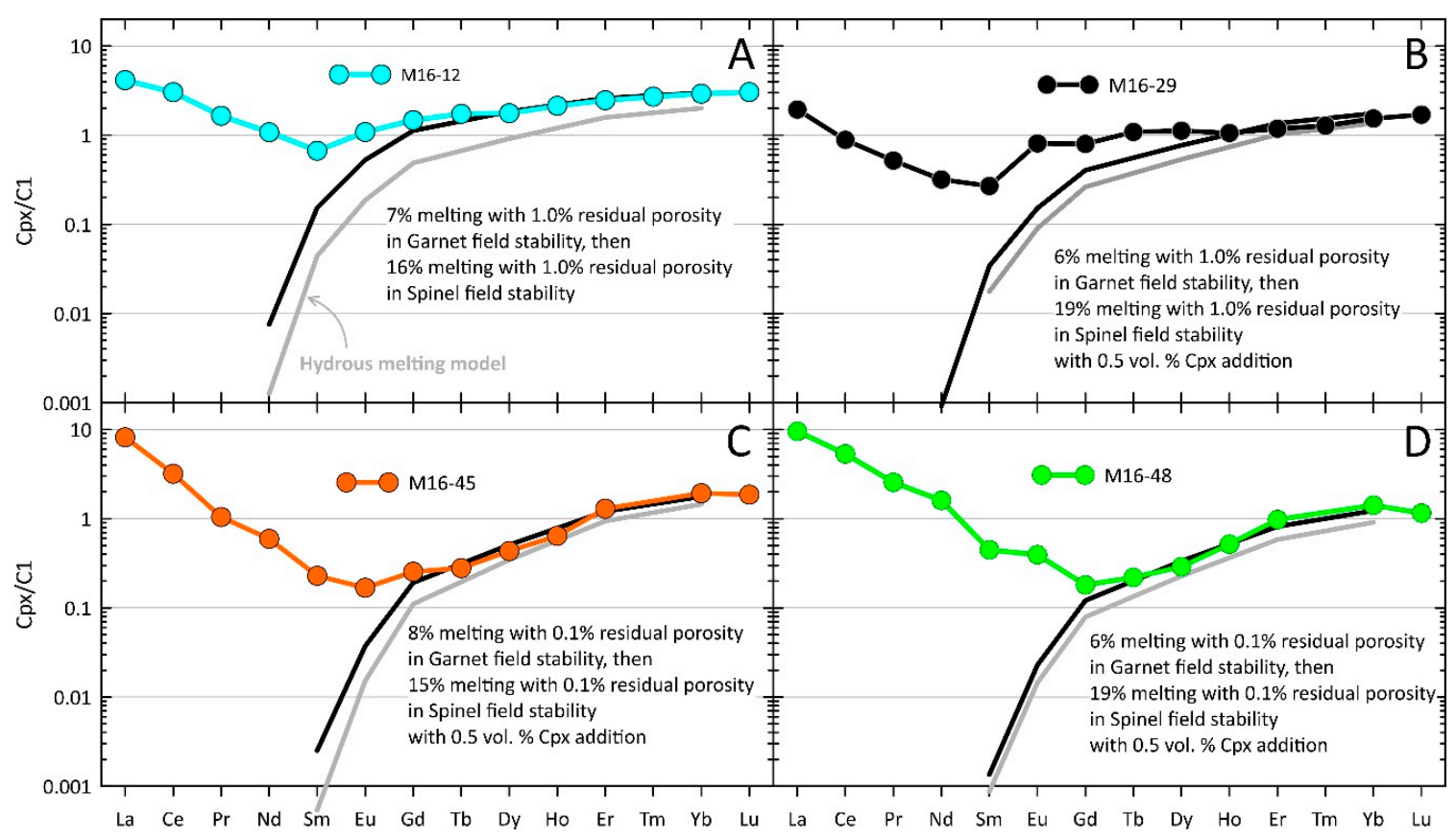

Figure 11. Modeling results of clinopyroxene composition for the polybaric continuous non-modal dynamic melting in the garnet, then in the spinel-peridotite facies. Composition of clinopyroxene1 from samples M16-12 (A), M16-29 (B), M16-45 (C), M16-48 (D) is shown for comparison. Black lines indicate anhydrous melting, and gray lines indicate hydrous melting. Equations for melting, polybaric model, and melting parameters (initial and melt modes, source composition, and mineral/melt partition coefficients) for anhydrous melting are from [60], and melting modes for hydrous melting are from [73]. See details in the text and Supplementary Table S3. Normalized to chondrite [52].

For the sample M16-11, we cannot simulate melting parameters for Cpx, since its HREE pattern does not correspond to the range of residual clinopyroxenes.

An estimate of a clinopyroxene compositional change due to peridotite interaction with percolated melt was done using the model of [70] for a simplified case, where new minerals do not crystallize. The same approach was utilized in [74]. In our case, we suggest that Cpx1 was present in the Alag Khadny harzburgites before refertilization by an exotic melt. For each sample, the clinopyroxene composition resulted from partial melting modeling (see above) was assumed as primary. Two melt compositions were considered: (1) melt in equilibrium with clinopyroxene of the most reacted sample M16-11, and (2) composition of dikes crosscutting the Alag Khadny peridotites.

The melt/peridotite interaction modeling results better fit the composition of basaltic dikes as reacting melt (Figure 12). The calculated and observed clinopyroxene compositions are almost coincident for the least reacted sample M16-12. For other samples, exact matching was not attained, 
probably due to variations in composition of percolating melts. The large proportion of clinopyroxene in M16-11 and its REE pattern might indicate high melt/rock ratio and crystallization of new phases during refertilization, and cannot be reproduced well by this simplified model.

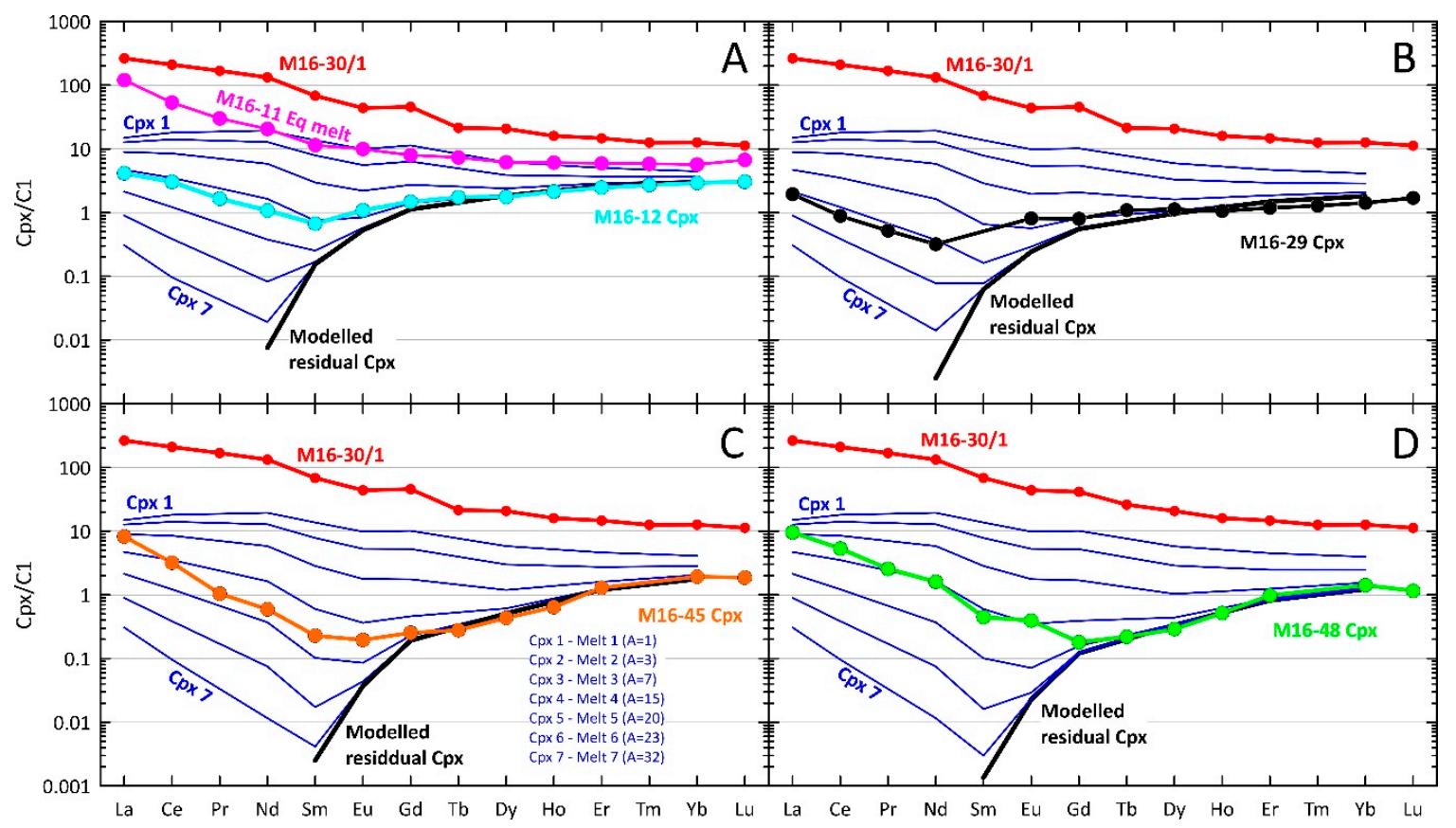

Figure 12. Simulation of REE variations of clinopyroxene in the Alag Khadny peridotites, samples M16-12 (A), M16-29 (B), M16-45 (C), M16-48 (D). The modeling parameters, partition coefficients, and simplified equation are from [70]. The modeling assumes redistribution of REE by reaction between percolating melt (sample M16-30/1, dike of calc-alkaline basalt cutting Alag Khadny peridotites) and clinopyroxene in residual harzburgite (modeled residual Cpx for each sample from Figure 8). “A" represents Cpx/melt ratio; Cpx 1 to Cpx 7-equilibrium Cpx for evolved Melt 1 to Melt 7, respectively. Normalized to chondrite [52]. Modeling parameters and results are given in Supplementary Table S3.

\subsection{Metamorphism of the Peridotites}

Metamorphic minerals of Alag Khadny peridotites are represented by chlorite, tremolite, $\mathrm{Ol3}, \mathrm{Ol} 4$, Cpx2, Cpx3, antigorite, chrysotile, and Cr-magnetite. The rocks preserved mineral associations formed during different stages of metamorphism. Chlorite commonly occurs around spinel with rim of Cr-magnetite; thus, chlorite formation is related to Al release from the spinel. Tremolite is developed after orthopyroxene and is associated with metamorphic $\mathrm{Ol} 3$ of similar grain size. Moreover, pseudomorphs after orthopyroxene also contain fibrous secondary Cpx2 and antigorite. Antigorite flakes formed after O11 and O12.

Pressure-temperature conditions of metamorphism of ultramafic rocks could be estimated from diagnostic mineral associations in $\mathrm{MgO}-\mathrm{CaO}-\mathrm{Al}_{2} \mathrm{O}_{3}-\mathrm{SiO}_{2}-\mathrm{H}_{2} \mathrm{O}$ system. Figure 13 is a $\mathrm{P}-\mathrm{T}$ diagram of equilibrium reactions in this system, calculated by [75] based on thermodynamic data from [76,77]. Mineral associations of the Alag Khadny peridotites could form gradually, as a result of the addition of water and a decrease of temperature, according to reactions shown on Figure 13:

$$
\begin{gathered}
\mathrm{Ol}+\mathrm{En}+\mathrm{Sp}+\mathrm{H}_{2} \mathrm{O} \rightarrow \mathrm{Chl}(11) \\
\mathrm{En}+\mathrm{Di}+\mathrm{H}_{2} \mathrm{O} \rightarrow \mathrm{Tr}+\mathrm{Fo}(10) \\
\mathrm{En}+\mathrm{Fo}+\mathrm{H}_{2} \mathrm{O} \rightarrow \operatorname{Atg}(4) \\
\mathrm{Tr}+\mathrm{Fo}+\mathrm{H}_{2} \mathrm{O} \rightarrow \mathrm{Di}+\mathrm{Atg}(7)
\end{gathered}
$$




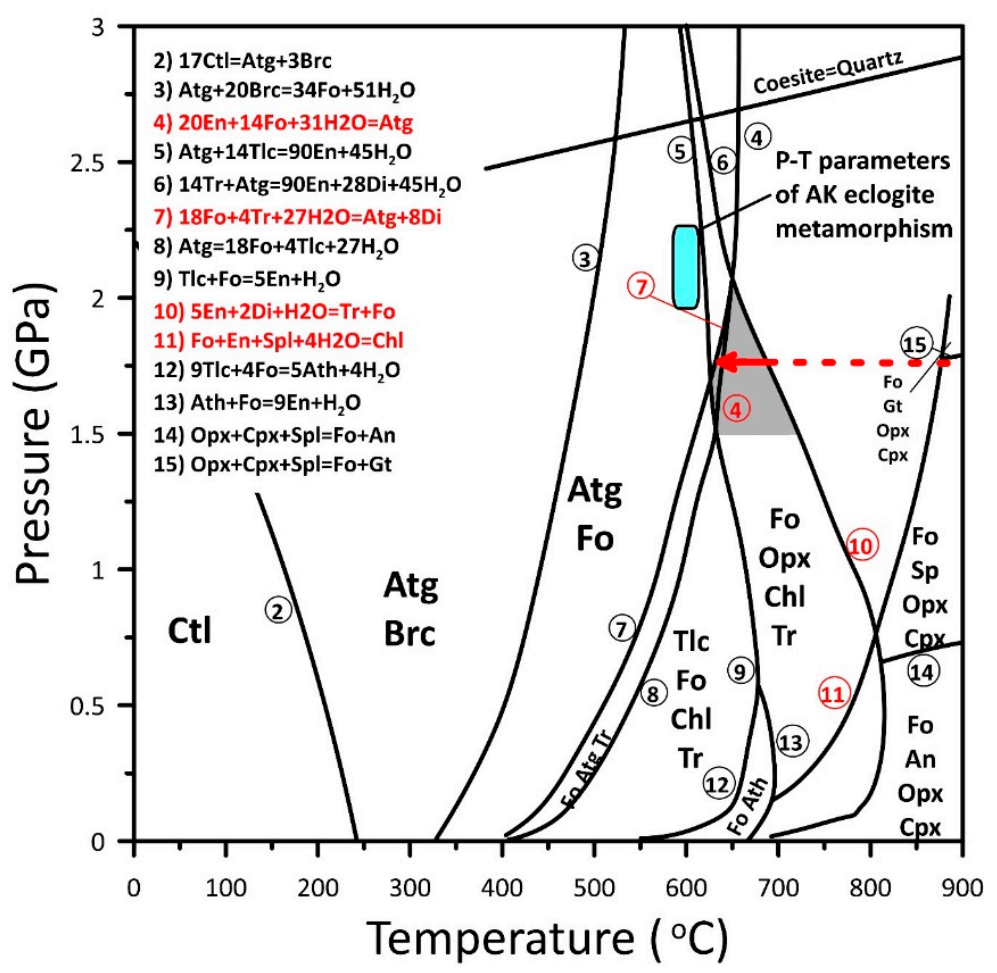

Figure 13. P-T conditions of metamorphism of the Alag Khadny peridotites, diagram after [75]. The gray area represents stability field of metamorphic mineral association of Alag Khadny peridotites. The red arrow indicates inferred $\mathrm{P}-\mathrm{T}$ path of peridotites metamorphism. P-T parameters of peak metamorphism of Alag Khadny eclogite are from [22].

Cpx1 is not replaced by tremolite according to reaction (10) probably due to addition of Ca from a fluid. Association of olivine + orthopyroxene + chlorite + tremolite is stable within a wide interval of temperature $\left(640-800{ }^{\circ} \mathrm{C}\right.$ ) and pressure (up to $2 \mathrm{GPa}$ ) (Figure 13). The studied rocks do not exhibit formation of talc (reaction 9) or anthophyllite (Reaction (13)). Instead, antigorite is formed from reactions (4) and (7). As Figure 12 demonstrates, this is possible only in narrow range of pressure (1.6-2.0 GPa) and temperature $\left(640-720^{\circ} \mathrm{C}\right)$, corresponding to mantle-wedge conditions. $\mathrm{O} 14$ and $\mathrm{Cpx3}$ are always present next to serpentine veinlets; therefore, formation of O14 and Cpx3 is apparently related to fluid migration, similar to the process recorded by serpentinized mantle wedge peridotites [62]. Low-temperature chrysotile veinlets, cutting through both $\mathrm{Ol1}$ and Ol2, and pseudomorphs after orthopyroxene, formed at a lower temperature, either in SSZ or in the crust. To summarize, metamorphism of the Alag Khadny peridotites is retrograde, showing incomplete metamorphic reactions and high pressure. This is consistent with metamorphism in the mantle wedge. Water flux from subducting slab into the mantle wedge peridotites is responsible for the formation of hydrous minerals in a wide temperature range [12,13,78].

\subsection{Implications to Regional Tectonics and Concluding Remarks}

The present study provides the evidence that the Alag Khadny metaperidotites represent the former oceanic peridotites subjected to multistage modification by melts of the suprasubduction affinity and hydrous fluids in the mantle wedge. The rocks exhibit incompatible elements distribution that is characteristic of mantle-wedge peridotites, such as enrichment in LILE, L-MREE, $\mathrm{Nb}, \mathrm{Zr}$, and $\mathrm{Hf}$ relative to $\mathrm{HREE}$, peaks of $\mathrm{Pb}, \mathrm{Sr}$, and weak minima of $\mathrm{Nb}, \mathrm{Zr}$, and $\mathrm{Hf}$. The clinopyroxene is enriched in fluid-mobile $\mathrm{Li}$ and $\mathrm{B}$. Moreover, the rocks suffered retrograde metamorphism in the mantle wedge ( $P \sim 1.6-2.0 \mathrm{GPa}, T \sim 640-720^{\circ} \mathrm{C}$ ). From mineral and bulk-rock composition and HREE distribution, the Alag Khadny peridotites are transitional between the abyssal and supra-subduction peridotites. The rocks contain interstitial magmatic Cpx. The HREE abundances in clinopyroxene reflect 5-8\% 
melting in garnet-facies, followed by $\sim 15-20 \%$ in spinel-facies melting. The Alag Khadny harzburgites show geochemical signatures of refertilization with percolating melts, such as enrichment in LREE, lack of notable HFSE depletion relative to REE, and lack of correlation between LREE abundances and melting degree. The simulation of REE pattern in clinopyroxene demonstrates that the interacting melt could be a calc-alkaline basaltic melt probably originated in rear-arc setting. All the above features point at a multistage history of the Alag Khadny peridotites formation, which is schematically shown on Figure 14.
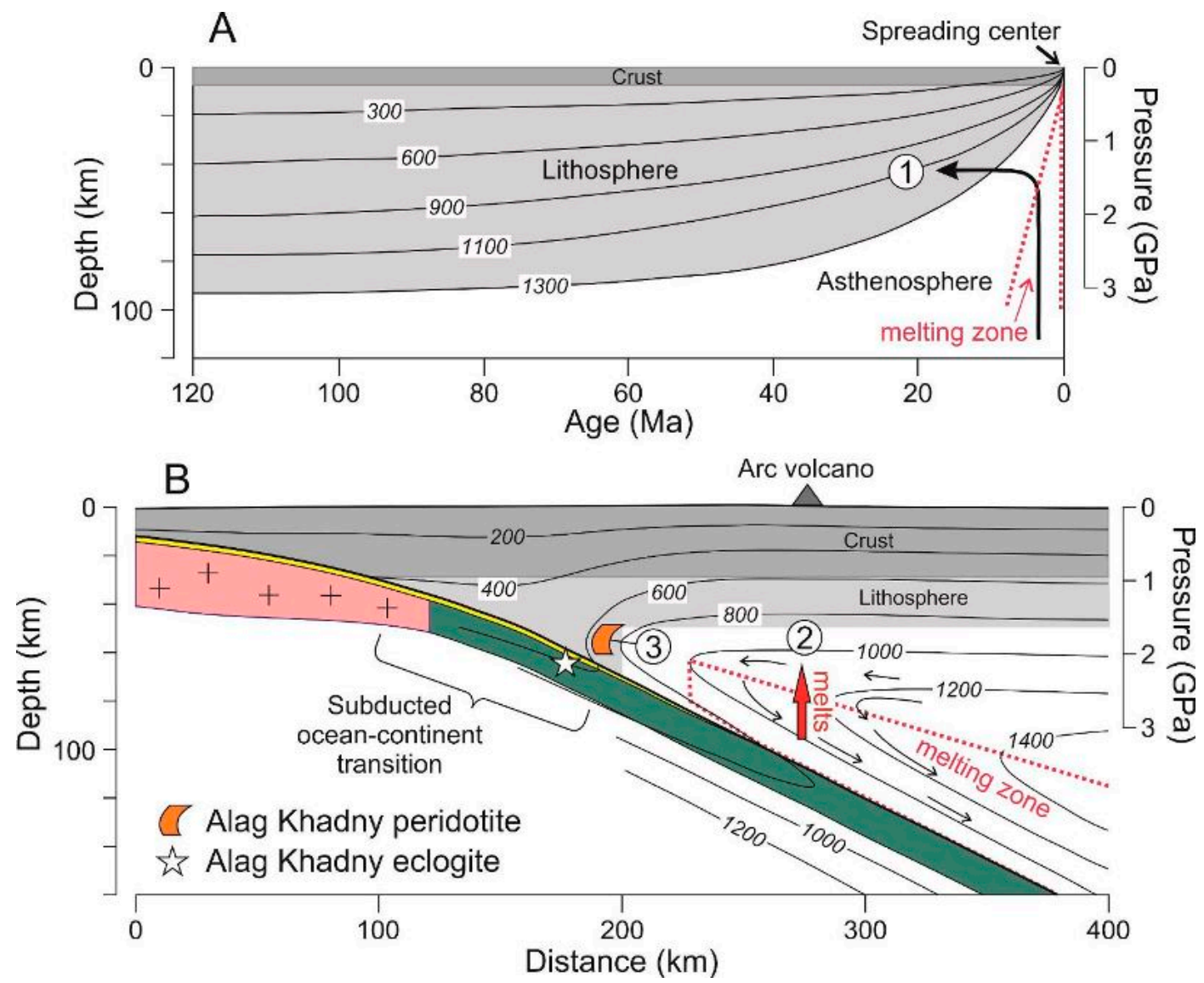

Figure 14. A schematic model of Alag Khadny peridotite formation. The numbers 1, 2, and 3 denote stages of Alag Khadny peridotites formation: (1) decompression melting at a spreading center (A), followed by (2) melt refertilization and (3) metamorphism above subduction zone (B). Thermal structure of oceanic lithosphere is after [79]. The thermal structure of subduction zone beneath SW Japan [80] with geothermal gradient of $\sim 10^{\circ} \mathrm{C} / \mathrm{km}$ is used for the model, since this subduction zone exhibit P-T path similar to that recorded in Alag Khadny eclogite $\left(\sim 8^{\circ} \mathrm{C} / \mathrm{km}\right.$; [22]). Melting zone region above SZ is after [81]. Locations of metamorphism according to P-T conditions determined for the Alag Khadny peridotites (this study) and eclogites [22] are shown by orange field and white star, respectively. See discussion in the text.

Stage $1-$ mantle melting and the origin of the precursor harzburgites. From mineral composition systematics and inferred melt metasomatism, competing oceanic and mantle-wedge origin can be invoked. The flux melting of mantle-wedge peridotites with the formation of calc-alkaline basaltic melts occurs in the lower part of the mantle wedge [81], and the residue can be then dredged down by mantle flow (Figure 14B). However, it is very unlikely that the Alag Khadny peridotites experienced melting in the mantle wedge, as the rocks would need to be transported to the melt-refertilization zone and then into slab-mantle interface, to experience subsequent subduction-related metamorphism facilitated by suprasubduction fluids. Hence, it is more possible that the Alag Khadny peridotites 
formed via of decompression melting of asthenosphere at a spreading center (Figure 14A). If so, melting started in the garnet-facies conditions and continued in the spinel facies. Spinel-facies melting could be anhydrous if occurred at a mid-ocean ridge, or hydrous if happened at a back-arc spreading center, with contribution from a subduction component. Shortly after a final stage of melting, newly formed clinopyroxene and observed textural features could appear due to interaction of residue with percolating melts. These melts originated from a lower part of the mantle column during the melting event. Though no direct evidence exists on the age of the studied ultramafic rocks, we may argue based on the regional tectonics that the Alag Khadny peridotites may represent remnants of the Early Neoproterozoic or earlier oceanic lithosphere [25].

Stage 2-melt refertilization. Following decompression melting associated with the growth of the oceanic lithosphere, the Alag Khadny peridotites were transported to the mantle wedge and subjected to the refertilization process, most likely in the upper part of the mantle wedge above melt generation zone (Figure 14B). Based on [23,25], tectonic evolution of the Alag Khadny complex and adjacent geological structures might involve two stage of the Late Neoproterozoic-Early Cambrian subduction events of different polarities, which led to eclogitization of the rifted continental margin ( 550-540 Ma) and further reworking the Precambrian complexes by widespread suprasubduction magmatism ( 540-530 Ma). According to [23,25] the protoliths of the Alag Khadny eclogites and metasediments formed at the passive continental margin that experienced subduction-related metamorphism in the Late Ediacaran. The continuous subduction of the oceanic lithosphere, followed by continental subduction, as it is recorded in other orogenic belts [82], may be responsible for melt generation and corresponding melt metasomatism of mantle peridotites.

Stage 3-metamorphism. Following refertilization, the peridotites were moved to a low-temperature area of the mantle wedge by horizontal mantle flow. In this region, the peridotites were modified by supra-subduction fluids and experienced metamorphism. Importantly, metamorphosed harzburgites of the Alag Khadny complex are associated with eclogites with similar P-T conditions of peak metamorphism (2.0-2.3 GPa and 590-610 ${ }^{\circ} \mathrm{C}$ [22]). An association of eclogites and mantle peridotites is common in orogenic belts and is interpreted as a result of adjustment of subducted oceanic crust and mantle-wedge peridotites, their metamorphism, and their subsequent exhumation [83]. Therefore, both metaperidotites and eclogites show similar P-T conditions, suggestive of their metamorphism in a single subduction zone (Figure 14B), followed by joint exhumation and incorporation into the Alag Khadny accretionary complex in the Late Ediacaran.

Supplementary Materials: The following are available online at http://www.mdpi.com/2075-163X/10/5/396/s1. Figure S1: Field photograph of a calc-alkaline basaltic dike cutting the Alag Khadny harzburgites; Table S1: Major and trace (only for Cpx) elements of peridotite minerals; Table S2: Whole-rock analyses (major and trace elements) of the Alag Khadny peridotites; Table S3: Parameters of the melting and refertilization modeling.

Author Contributions: Conceptualization, M.G., A.K., and S.S.; methodology and investigation, M.G. and A.K.; writing-original draft preparation, M.G., A.K., S.S., and V.B.; writing—review and editing, M.G., A.K., S.S., and V.B.; funding acquisition, S.S. All authors have read and agreed to the published version of the manuscript.

Funding: This research was funded by the IGC State Assignment Project 0350-2019-0008 and the Russian Federation President Foundation Grant MK-549.2018.5, the additional Grant 18-35-00535 from the Russian Foundation for Basic Research.

Acknowledgments: The authors are grateful to Olga Belozerova (IGC) for assisting EPMA studies, as well as to Sergei Simakin (IPT, Yaroslavl) for performing SIMS analyses of minerals. Two anonymous reviewers are thanked for comments that helped to improve the manuscript significantly.

Conflicts of Interest: The authors declare no conflict of interest.

\section{References}

1. Deschamps, F.; Godard, M.; Guillot, S.; Hattori, K. Geochemistry of subduction zone serpentinites: A review. Lithos 2013, 178, 96-127. [CrossRef]

2. Spandler, C.; Pirard, C. Element recycling from subducting slabs to arc crust: A review. Lithos 2013, 170-171, 208-223. [CrossRef] 
3. Scambelluri, M.; Pettke, T.; Cannaò, E. Fluid-related inclusions in Alpine high-pressure peridotite reveal trace element recycling during subduction-zone dehydration of serpentinized mantle (Cima di Gagnone, Swiss Alps). Earth Planet. Sci. Lett. 2015, 429, 45-59. [CrossRef]

4. Kendrick, M.A.; Hémond, C.; Kamenetsky, V.S.; Danyushevsky, L.; Devey, C.W.; Rodemann, T.; Jackson, M.G.; Perfit, M.R. Seawater cycled throughout Earth's mantle in partially serpentinized lithosphere. Nat. Geosci. 2017, 10, 222-228. [CrossRef]

5. Scambelluri, M.; Pettke, T.; Rampone, E.; Godard, M.; Reusser, E. Petrology and Trace Element Budgets of High-pressure Peridotites Indicate Subduction Dehydration of Serpentinized Mantle (Cima di Gagnone, Central Alps, Switzerland). J. Petrol. 2014, 55, 459-498. [CrossRef]

6. Bebout, G.E. Metamorphic chemical geodynamics of subduction zones. Earth Planet. Sci. Lett. 2007, 260, 373-393. [CrossRef]

7. Guillot, S.; Schwartz, S.; Reynard, B.; Agard, P.; Prigent, C. Tectonic significance of serpentinites. Tectonophysics 2015, 646, 1-19. [CrossRef]

8. Cannaò, E.; Agostini, S.; Scambelluri, M.; Tonarini, S.; Godard, M. B, Sr and Pb isotope geochemistry of high-pressure Alpine metaperidotites monitors fluid-mediated element recycling during serpentinite dehydration in subduction mélange (Cima di Gagnone, Swiss Central Alps). Geochim. Cosmochim. Acta 2015, 163, 80-100. [CrossRef]

9. Guillot, S.; Hattori, K.H.; De Sigoyer, J.; Nägler, T.; Auzende, A.-L. Evidence of hydration of the mantle wedge and its role in the exhumation of eclogites. Earth Planet. Sci. Lett. 2001, 193, 115-127. [CrossRef]

10. Bostock, M.G.; Hyndman, R.D.; Rondenay, S.; Peacock, S.M. An inverted continental Moho and serpentinization of the forearc mantle. Nature 2002, 417, 536-538. [CrossRef]

11. Savov, I.P.; Ryan, J.G.; D’Antonio, M.; Kelley, K.; Mattie, P. Geochemistry of serpentinized peridotites from the Mariana Forearc Conical Seamount, ODP Leg 125: Implications for the elemental recycling at subduction zones: Serpentinized peridotites. Geochem. Geophys. Geosystems 2005, 6, 1-24. [CrossRef]

12. Khedr, M.Z.; Arai, S. Hydrous peridotites with Ti-rich chromian spinel as a low-temperature forearc mantle facies: Evidence from the Happo-O'ne metaperidotites (Japan). Contrib. Mineral. Petrol. 2010, 159, 137-157. [CrossRef]

13. Khedr, M.Z.; Arai, S.; Tamura, A.; Morishita, T. Clinopyroxenes in high-P metaperidotites from Happo-O'ne, central Japan: Implications for wedge-transversal chemical change of slab-derived fluids. Lithos 2010, 119, 439-456. [CrossRef]

14. Shervais, J.W.; Jean, M.M. Inside the subduction factory: Modeling fluid mobile element enrichment in the mantle wedge above a subduction zone. Geochim. Cosmochim. Acta 2012, 95, 270-285. [CrossRef]

15. Le Roux, V.; Liang, Y. Ophiolitic Pyroxenites Record Boninite Percolation in Subduction Zone Mantle. Minerals 2019, 9, 565. [CrossRef]

16. Ishimaru, S.; Saikawa, Y.; Miura, M.; Parlak, O.; Arai, S. Decoding of Mantle Processes in the Mersin Ophiolite, Turkey, of End-Member Arc Type: Location of the Boninite Magma Generation. Minerals 2018, 8, 464. [CrossRef]

17. Zheng, J.; Xiong, Q.; Zhao, Y.; Li, W. Subduction-zone peridotites and their records of crust-mantle interaction. Sci. China Earth Sci. 2019, 62, 1033-1052. [CrossRef]

18. Angiboust, S.; Agard, P.; Raimbourg, H.; Yamato, P.; Huet, B. Subduction interface processes recorded by eclogite-facies shear zones (Monviso, W. Alps). Lithos 2011, 127, 222-238. [CrossRef]

19. Hermann, J.; Müntener, O.; Scambelluri, M. The importance of serpentinite mylonites for subduction and exhumation of oceanic crust. Tectonophysics 2000, 327, 225-238. [CrossRef]

20. Schwartz, S.; Allemand, P.; Guillot, S. Numerical model of the effect of serpentinites on the exhumation of eclogitic rocks: Insights from the Monviso ophiolitic massif (Western Alps). Tectonophysics 2001, 342, 193-206. [CrossRef]

21. Lehmann, J.; Schulmann, K.; Lexa, O.; Corsini, M.; Kroner, A.; Stipska, P.; Tomurhuu, D.; Otgonbator, D. Structural constraints on the evolution of the Central Asian Orogenic Belt in SW Mongolia. Am. J. Sci. 2010, 310, 575-628. [CrossRef]

22. Štípská, P.; Schulmann, K.; Lehmann, J.; Corsini, M.; Lexa, O.; Tomurhuu, D. Early Cambrian eclogites in SW Mongolia: Evidence that the Palaeo-Asian Ocean suture extends further east than expected: Cambrian eclogites in SW Mongolia. J. Metamorph. Geol. 2010, 28, 915-933. [CrossRef] 
23. Skuzovatov, S.Y.; Shatsky, V.S.; Dril, S.I.; Perepelov, A.B. Elemental and isotopic (Nd-Sr-O) geochemistry of eclogites from the Zamtyn-Nuruu area (SW Mongolia): Crustal contribution and relation to Neoproterozoic subduction-accretion events. J. Asian Earth Sci. 2018, 167, 33-51. [CrossRef]

24. Kozakov, I.K.; Sal'nikova, E.B.; Wang, T.; Didenko, A.N.; Plotkina, Y.V.; Podkovyrov, V.N. Early Precambrian crystalline complexes of the Central Asian microcontinent: Age, sources, tectonic position. Stratigr. Geol. Correl. 2007, 15, 121-140. [CrossRef]

25. Buriánek, D.; Schulmann, K.; Hrdličková, K.; Hanžl, P.; Janoušek, V.; Gerdes, A.; Lexa, O. Geochemical and geochronological constraints on distinct Early-Neoproterozoic and Cambrian accretionary events along southern margin of the Baydrag Continent in western Mongolia. Gondwana Res. 2017, 47, 200-227. [CrossRef]

26. Skuzovatov, S.Y.; Wang, K.-L.; Lee, H.-Y. Nature and (in-)coherent metamorphic evolution of subducted continental crust in the Neoproterozoic accretionary collage of SW Mongolia. Geosci. Front. 2020, under review.

27. Kovalenko, V.I.; Yarmolyuk, V.V.; Kovach, V.P.; Kotov, A.B.; Kozakov, I.K.; Salnikova, E.B.; Larin, A.M. Isotope provinces, mechanisms of generation and sources of the continental crust in the Central Asian mobile belt: Geological and isotopic evidence. J. Asian Earth Sci. 2004, 23, 605-627. [CrossRef]

28. Kröner, A.; Kovach, V.; Alexeiev, D.; Wang, K.-L.; Wong, J.; Degtyarev, K.; Kozakov, I. No excessive crustal growth in the Central Asian Orogenic Belt: Further evidence from field relationships and isotopic data. Gondwana Res. 2017, 50, 135-166. [CrossRef]

29. Yarmolyuk, V.V.; Kovach, V.P.; Kovalenko, V.I.; Salnikova, E.B.; Kozlovskii, A.M.; Kotov, A.B.; Yakovleva, S.Z.; Fedoseenko, A.M. Composition, sources, and mechanism of continental crust growth in the Lake zone of the Central Asian Caledonides: I. Geological and geochronological data. Petrology 2011, 19, 55-78. [CrossRef]

30. Hanžl, P.; Aichler, J.; Bolormaa, K.; Budil, P.; Buriánek, D.; Hrdličková, K.; Erban, V.; Gerdes, A.; Gilíková, H.; Holák, J.; et al. Geological Survey of the Mongolian Altay at a Scale 1:50.000 (Zamtyn Nuruu—50); Czech Geological Survey: Prague, Czech Republic, 2007; p. 376.

31. Kröner, A.; Lehmann, J.; Schulmann, K.; Demoux, A.; Lexa, O.; Tomurhuu, D.; Stipska, P.; Liu, D.; Wingate, M.T.D. Lithostratigraphic and geochronological constraints on the evolution of the Central Asian Orogenic Belt in SW Mongolia: Early Paleozoic rifting followed by late Paleozoic accretion. Am. J. Sci. 2010, 310, 523-574. [CrossRef]

32. Tomurtogoo, O. Geology of Ophiolitic Complex of Mongolia; Geological Funds of Mongolia: Ulanbaatar, Mongolia, 1980.

33. Perfiliev, A.S.; Kheraskov, N.N. Diabase complexes and the problem of tectonic stratification of oceanic crust. In Tectonic Layering of Lithosphere; Nauka: Moscow, Russia, 1980; Volume 343, pp. 64-104.

34. Gornova, M.A.; Enkhbat, D.; Karimov, A.A.; Belyaev, V.A.; Gerel, O.; Javkhlan, O. Petrography and mineralogy of retrograde metaperidotites from Alag Khadny accretionary wedge (SW Mongolia): Fluid modification in suprasubduction zone. Geodyn. Tectonophys. 2017, 8, 465-469. [CrossRef]

35. Demoux, A.; Kröner, A.; Badarch, G.; Jian, P.; Tomurhuu, D.; Wingate, M.T.D. Zircon Ages from the Baydrag Block and the Bayankhongor Ophiolite Zone: Time Constraints on Late Neoproterozoic to Cambrian Subduction- and Accretion-Related Magmatism in Central Mongolia. J. Geol. 2009, 117, 377-397. [CrossRef]

36. Amosova, A.A.; Panteeva, S.V.; Tatarinov, V.V.; Chubarov, V.M.; Finkelstein, A.L. X-ray fluorescence determination of major rock forming elements in small samples 50 and $110 \mathrm{mg}$. Anal. Control. 2015, 19, 130-138.

37. Bottazzi, P.; Ottolini, L.; Vanucci, R.; Zanetti, A. An accurate procedure for the quantification of rare earth elements in silicates. In Proceedings of the Secondary Ion Mass Spectrometry; Wiley: Yokohama, Japan, 1994; pp. 927-930.

38. Mercier, J.-C.C.; Nicolas, A. Textures and Fabrics of Upper-Mantle Peridotites as Illustrated by Xenoliths from Basalts. J. Petrol. 1975, 16, 454-487. [CrossRef]

39. Seyler, M.; Lorand, J.-P.; Dick, H.J.B.; Drouin, M. Pervasive melt percolation reactions in ultra-depleted refractory harzburgites at the Mid-Atlantic Ridge, $15^{\circ} 20^{\prime} \mathrm{N}$ : ODP Hole 1274A. Contrib. Mineral. Petrol. 2007, 153, 303-319. [CrossRef]

40. Dick, H.J.B.; Bullen, T. Chromian spinel as a petrogenetic indicator in abyssal and alpine-type peridotites and spatially associated lavas. Contrib. Mineral. Petrol. 1984, 86, 54-76. [CrossRef]

41. Parkinson, I.J.; Pearce, J.A. Peridotites from the Izu-Bonin-Mariana Forearc (ODP Leg 125): Evidence for Mantle Melting and Melt-Mantle Interaction in a Supra-Subduction Zone Setting. J. Petrol. 1998, 39, 1577-1618. [CrossRef] 
42. Evans, B.; Frost, R. Chrome-spinel in progressive metamorphism-A preliminary analysis. Geochim. Cosmochim. Acta 1975, 39, 959-972. [CrossRef]

43. Arai, S. Characterization of spinel peridotites by olivine-spinel compositional relationships: Review and interpretation. Chem. Geol. 1994, 113, 191-204. [CrossRef]

44. Hellebrand, E.; Snow, J.E.; Dick, H.J.B.; Hofmann, A.W. Coupled major and trace elements as indicators of the extent of melting in mid-ocean-ridge peridotites. Nature 2001, 410, 677-681. [CrossRef]

45. Takahashi, E.; Uto, K.; Schilling, J.-G. Primary Magma Compositions and Mg/Fe Ratios of Their Mantle Residues along Mid Atlantic Ridge 29 N to73 N; Okayama University: Okayama, Japan, 1987; pp. 1-4.

46. Workman, R.K.; Hart, S.R. Major and trace element composition of the depleted MORB mantle (DMM). Earth Planet. Sci. Lett. 2005, 231, 53-72. [CrossRef]

47. Seyler, M.; Cannat, M.; Mével, C. Evidence for major-element heterogeneity in the mantle source of abyssal peridotites from the Southwest Indian Ridge (52 $2^{\circ}$ to $\left.68^{\circ} \mathrm{E}\right)$ : Major-element heterogenity. Geochem. Geophys. Geosyst. 2003, 4, 1-33. [CrossRef]

48. Hellebrand, E. Garnet-field Melting and Late-stage Refertilization in "Residual" Abyssal Peridotites from the Central Indian Ridge. J. Petrol. 2002, 43, 2305-2338. [CrossRef]

49. Ishii, T.; Robinson, P.T.; Maekava, H.; Fiske, R. Petrological studies of peridotites from diapiric serpentinite seamounts in the Izu-Ogasawara-Mariana Forearc, Leg 125. In Proceedings of the Ocean Drilling Program, 125 Scientific Results; Fryer, P., Pearce, J.A., Stokking, L.B., Ali, J.R., Arculus, R., Balotti, D., Burke, M.M., Ciampo, G., Haggerty, J.A., Haston, R.B., et al., Eds.; Ocean Drilling Program: College Station, TX, USA, 1992; Volume 125, pp. 445-485. [CrossRef]

50. Herzberg, C. Geodynamic Information in Peridotite Petrology. J. Petrol. 2004, 45, 2507-2530. [CrossRef]

51. Niu, Y. Bulk-rock Major and Trace Element Compositions of Abyssal Peridotites: Implications for Mantle Melting, Melt Extraction and Post-melting Processes Beneath Mid-Ocean Ridges. J. Petrol. 2004, 45, 2423-2458. [CrossRef]

52. McDonough, W.F.; Sun, S.-S. The composition of the Earth. Chem. Geol. 1995, 120, 223-253. [CrossRef]

53. Jagoutz, E.; Palme, H.; Baddenhausen, H.B.; Cendales, M.; Dreibus, G. The abundances of major, minor and trace elements in the earth's mantle as derived from primitive ultramafic nodules. In Proceedings of the Lunar and Planetary Science Conference, Houston, TX, USA, 19-23 March 1979; Volume 2, pp. 2031-2050.

54. Malvoisin, B. Mass transfer in the oceanic lithosphere: Serpentinization is not isochemical. Earth Planet. Sci. Lett. 2015, 430, 75-85. [CrossRef]

55. Marchesi, C.; Garrido, C.J.; Proenza, J.A.; Hidas, K.; Varas-Reus, M.I.; Butjosa, L.; Lewis, J.F. Geochemical record of subduction initiation in the sub-arc mantle: Insights from the Loma Caribe peridotite (Dominican Republic). Lithos 2016, 252-253, 1-15. [CrossRef]

56. Johnson, K.T.M.; Dick, H.J.B.; Shimizu, N. Melting in the oceanic upper mantle: An ion microprobe study of diopsides in abyssal peridotites. J. Geophys. Res. 1990, 95, 2661-2678. [CrossRef]

57. Bizimis, M.; Salters, V.J.M.; Bonatti, E. Trace and REE content of clinopyroxenes from supra-subduction zone peridotites. Implications for melting and enrichment processes in island arcs. Chem. Geol. 2000, 165, 67-85. [CrossRef]

58. Parkinson, I.J.; Johnson, K.T.M.; Ingram, G. Trace element geochemistry of peridotites from the Izu-Bonin-Mariana Forearc, Leg 125. In Proceedings of the Ocean Drilling Program, 125 Scientific Results, Tokyo, Japan, 15 February-17 April 1989; Fryer, P., Pearce, J.A., Stokking, L.B., Ali, J.R., Arculus, R., Balotti, D., Burke, M.M., Ciampo, G., Haggerty, J.A., Haston, R.B., et al., Eds.; Ocean Drilling Program: College Station, TX, USA, 1992; Volume 125, pp. 487-506. [CrossRef]

59. Liu, X.; Neil, H.S.C. The Effect of $\mathrm{Cr} 2 \mathrm{O} 3$ on the Partial Melting of Spinel Lherzolite in the System $\mathrm{CaO}-\mathrm{MgO}-\mathrm{Al}_{2} \mathrm{O}_{3}-\mathrm{SiO}_{2}-\mathrm{Cr}_{2} \mathrm{O}_{3}$ at $1.1 \mathrm{GPa}$. J. Petrol. 2004, 45, 2261-2286. [CrossRef]

60. Brunelli, D.; Seyler, M.; Cipriani, A.; Ottolini, L.; Bonatti, E. Discontinuous Melt Extraction and Weak Refertilization of Mantle Peridotites at the Vema Lithospheric Section (Mid-Atlantic Ridge). J. Petrol. 2006, 47, 745-771. [CrossRef]

61. Deschamps, F.; Guillot, S.; Godard, M.; Chauvel, C.; Andreani, M.; Hattori, K. In situ characterization of serpentinites from forearc mantle wedges: Timing of serpentinization and behavior of fluid-mobile elements in subduction zones. Chem. Geol. 2010, 269, 262-277. [CrossRef] 
62. Murata, K.; Maekawa, H.; Yokose, H.; Yamamoto, K.; Fujioka, K.; Ishii, T.; Chiba, H.; Wada, Y. Significance of serpentinization of wedge mantle peridotites beneath Mariana forearc, western Pacific. Geosphere 2009, 5, 90-104. [CrossRef]

63. Batanova, V.G. Mantle Lherzolites from Troodos Ophiolites: Mineralogy and Ion Probe Geochemistry of Clinopyroxenes. Mineral. Mag. 1994, 58A, 57-58. [CrossRef]

64. Ozawa, K.; Shimizu, N. Open-system melting in the upper mantle: Constraints from the Hayachine-Miyamori ophiolite, northeastern Japan. J. Geophys. Res. Solid Earth 1995, 100, 22315-22335. [CrossRef]

65. Pagé, P.; Bédard, J.H.; Tremblay, A. Geochemical variations in a depleted fore-arc mantle: The ordovician thetford mines ophiolite. Lithos 2009, 113, 21-47. [CrossRef]

66. Morishita, T.; Dilek, Y.; Shallo, M.; Tamura, A.; Arai, S. Insight into the uppermost mantle section of a maturing arc: The Eastern Mirdita ophiolite, Albania. Lithos 2011, 124, 215-226. [CrossRef]

67. Churikova, T.; Dorendorf, F.; Wörner, G. Sources and Fluids in the Mantle Wedge below Kamchatka, Evidence from Across-arc Geochemical Variation. J. Petrol. 2001, 42, 1567-1593. [CrossRef]

68. Vils, F.; Pelletier, L.; Kalt, A.; Müntener, O.; Ludwig, T. The Lithium, Boron and Beryllium content of serpentinized peridotites from ODP Leg 209 (Sites 1272A and 1274A): Implications for lithium and boron budgets of oceanic lithosphere. Geochim. Cosmochim. Acta 2008, 72, 5475-5504. [CrossRef]

69. Godard, M.; Bodinier, J.-L.; Vasseur, G. Effects of mineralogical reactions on trace element redistributions in mantle rocks during percolation processes: A chromatographic approach. Earth Planet. Sci. Lett. 1995, 133, 449-461. [CrossRef]

70. Vernières, J.; Godard, M.; Bodinier, J.-L. A plate model for the simulation of trace element fractionation during partial melting and magma transport in the Earth's upper mantle. J. Geophys. Res. Solid Earth 1997, 102, 24771-24784. [CrossRef]

71. Zou, H. Trace element fractionation during modal and nonmodal dynamic melting and open-system melting: A mathematical treatment. Geochim. Cosmochim. Acta 1998, 62, 1937-1945. [CrossRef]

72. Ersoy, E.Y. PETROMODELER (Petrological Modeler): A Microsoft ${ }^{\circledR}$ Excel@ spreadsheet program for modelling melting, mixing, crystallization and assimilation processes in magmatic systems. Turk. J. Earth Sci. 2013, 22, 115-125. [CrossRef]

73. Gaetani, G.A.; Grove, T.L. The influence of water on melting of mantle peridotite. Contrib. Mineral. Petrol. 1998, 131, 323-346. [CrossRef]

74. Tamura, A.; Arai, S.; Ishimaru, S.; Andal, E.S. Petrology and geochemistry of peridotites from IODP Site U1309 at Atlantis Massif, MAR 30 N: Micro- and macro-scale melt penetrations into peridotites. Contrib. Mineral. Petrol. 2008, 155, 491-509. [CrossRef]

75. Li, X.-P.; Rahn, M.; Bucher, K. Serpentinites of the Zermatt-Saas ophiolite complex and their texture evolution. J. Metamorph. Geol. 2004, 22, 159-177. [CrossRef]

76. Berman, R.G.; Engi, M.; Greenwood, H.J.; Brown, T.H. Derivation of Internally-Consistent Thermodynamic Data by the Technique of Mathematical Programming: A Review with Application the System $\mathrm{MgO}-\mathrm{SiO}_{2}-\mathrm{H}_{2} \mathrm{O}$. J. Petrol. 1986, 27, 1331-1364. [CrossRef]

77. Berman, R.G. Internally-Consistent Thermodynamic Data for Minerals in the System $\mathrm{Na}_{2} \mathrm{O}-\mathrm{K}_{2} \mathrm{O}-\mathrm{CaO}-$ $\mathrm{MgO}-\mathrm{FeO}-\mathrm{Fe}_{2} \mathrm{O}_{3}-\mathrm{Al}_{2} \mathrm{O}_{3}-\mathrm{SiO}_{2}-\mathrm{TiO}_{2}-\mathrm{H}_{2} \mathrm{O}-\mathrm{CO}_{2}$. J. Petrol. 1988, 29, 445-522. [CrossRef]

78. Savelieva, G.N.; Raznitsin, Y.N.; Merkulova, M.V. Metamorphism of peridotites in the mantle wedge above the subduction zone: Hydration of the lithospheric mantle. Dokl. Earth Sci. 2016, 468, 438-440. [CrossRef]

79. Davis, E.E.; Chapman, D.S. Lithosphere, Oceanic: Thermal Structure. Encycl. Solid Earth Geophys. 2011, 709-716. [CrossRef]

80. Peacock, S.M. Seismic Consequences of Warm Versus Cool Subduction Metamorphism: Examples from Southwest and Northeast Japan. Science 1999, 286, 937-939. [CrossRef] [PubMed]

81. Grove, T.L.; Till, C.B.; Lev, E.; Chatterjee, N.; Médard, E. Kinematic variables and water transport control the formation and location of arc volcanoes. Nature 2009, 459, 694-697. [CrossRef] 
82. Agard, P.; Vitale-Brovarone, A. Thermal regime of continental subduction: The record from exhumed HP-LT terranes (New Caledonia, Oman, Corsica). Tectonophysics 2013, 601, 206-215. [CrossRef]

83. Guillot, S.; Hattori, K.H.; De Sigoyer, J. Mantle wedge serpentinization and exhumation of eclogites: Insights from eastern Ladakh, northwest Himalaya. Geology 2000, 28, 199-202. [CrossRef]

(C) 2020 by the authors. Licensee MDPI, Basel, Switzerland. This article is an open access article distributed under the terms and conditions of the Creative Commons Attribution (CC BY) license (http://creativecommons.org/licenses/by/4.0/). 